\title{
Örgütsel Adalet ve Örgütsel Güvenin İşe Adanmışlık Üzerindeki Etkilerinin Belirlenmesi: Alanya Belediyesi Çalışanları Üzerine Bir Araştırma \\ (Determining the Effects of Organizational Justice and Organizational Trust on Job Engagement: A Study on Alanya Municipality Employees)
}

\section{Mehmet ÖZTÜRK (iD) a Kemal VATANSEVER (D) b}

a Alanya Alaaddin Keykubat Üniversitesi, Gazipaşa MRB MYO, Antalya, Türkiye. mehmet.ozturk@alanya.edu.tr

bAlanya Alaaddin Keykubat Üniversitesi, İktisadi ve İdari Bilimler Fakültesi. İşletme Bölümü, Antalya, Türkiye. kemal.vatansever@alanya.edu.tr

\begin{tabular}{|c|c|}
\hline MAKALE BİLGİSİ & ÖZET \\
\hline $\begin{array}{l}\text { Anahtar Kelimeler: } \\
\text { Örgütsel Adalet }\end{array}$ & $\begin{array}{l}\text { Amaç - Bu çalışmanın temel amacı örgütsel adalet ve örgütsel güvenin işe adanmışlı üzerindeki } \\
\text { etkilerinin belirlenmesidir. }\end{array}$ \\
\hline $\begin{array}{l}\text { Örgütsel Güven } \\
\text { İşe Adanmışlık }\end{array}$ & $\begin{array}{l}\text { Yöntem - Araştırmada örgütsel adalet algısının belirlenmesinde Niehoff ve Moorman (1993)'ın } \\
\text { geliştirmiş olduğu Örgütsel Adalet Ölçeği, Örgütsel Güven algısının belirlenmesinde Adams } \\
\text { (2004)'ün geliştirdiği Örgütsel Güven Ölçeği ve Schaufeli vd. (2006) tarafından geliştirilen İşe }\end{array}$ \\
\hline Alanya Belediyesi & $\begin{array}{l}\text { Adanmışlık Ölçeği kullanılmıştır. Araştırmada elde edilen veriler üzerinde, güvenilirlik, geçerlilik, } \\
\text { doğrulayıcı faktör analizleri yapılmış, yol analizleri ile de hipotezler test edilmiştir. }\end{array}$ \\
\hline $\begin{array}{l}\text { Gönderilme Tarihi } 26 \text { Eylül } \\
2020 \\
\text { Revizyon Tarihi } 2 \text { Aralık } 2020\end{array}$ & $\begin{array}{l}\text { Bulgular - Araştırma sonuçlarına göre etkileşim adaletinin yöneticiye güven, çalışma arkadaşlarına } \\
\text { güven ve örgüte güven boyutları üzerinde olumlu yönde etkisinin olduğu görülmüştür. İşlem } \\
\text { adaletinin örgüte ve yöneticiye güven boyutları üzerinde olumlu yönde etkisi gözlenirken, çalışma } \\
\text { arkadaşlarına güven boyutu üzerinde herhangi bir etkisi görülmemiştir. Bununla birlikte örgütsel } \\
\text { güvenin yöneticiye güven ve örgüte güven boyutlarının çalışanların işe adanmışlıkları üzerinde } \\
\text { olumlu yönde bir etkisinin olduğu sonucuna ulaşılmıştır. }\end{array}$ \\
\hline $\begin{array}{l}\text { Makale Kategorisi: } \\
\text { Araştırma Makalesi }\end{array}$ & $\begin{array}{l}\text { Tartışma - Etkileşim adaletinin örgütsel güvenin tüm boyutları üzerinde anlamlı bir etkisi } \\
\text { görülmüştür. Yöneticilerin çalışanlarla kurdukları iletişimde istek ve beklentilerini açık ve net bir } \\
\text { şekilde ifade etmesi, çalışanların örgütsel güveninin oluşmasında önemli bir etken olarak karşımıza } \\
\text { çıkmaktadır. İşlem adaletinin düşük seviyede de olsa örgüte ve yöneticiye güveni etkilediği } \\
\text { görülmektedir. Dolayısıyla örgütsel kararların alınma süreci ve bu kararların hangi ölçütler } \\
\text { çerçevesinde belirlendiğinin ortaya konulması çalışanları örgütlerine ve yöneticilerine olan } \\
\text { güvenlerini etkilediği çıkarımı yapılabilir. Bununla birlikte araştırma sonuçlarına göre; çalışanların } \\
\text { işe adanmışlıklarının sağlanmasında ise örgüte ve yöneticiye güvenin sağlanmasının önemli bir } \\
\text { faktör olarak ortaya çıtığı yorumu yapılabilmektedir. }\end{array}$ \\
\hline
\end{tabular}

\begin{tabular}{l}
\hline ARTICLE INFO \\
\hline Keywords: \\
Organizational Justice \\
Organizational Trust \\
Job Engagement \\
Alanya Municipality
\end{tabular}

\section{ABSTRACT}

Purpose - The main aim of this study is to determine the effects of organizational justice and organizational trust on job engagement.

Design/methodology/approach - In the study, the Organizational Justice Scale developed by Niehoff ve Moorman (1993) was used for determining the perception of organizational justice, the Organizational Trust Scale developed by Adams (2004) was used for determining the perception of organizational trust and Job Engagement Scale developed by Schaufeli et al. (2006) was used for determining the perception of job engagement. Reliability, validity, and confirmatory factor analyzes were performed on the data obtained in the study, and the hypotheses were tested with path analysis.

Received 26 September 2020

Revised 2 December 2020

Accepted 12 December 2020

Article Classification:

Research Article
Findings - According to the results of the research, it has been observed that interaction justice has a positive effect on the dimensions of trust in the manager, trust in colleagues, and trust in the organization. While procedural fairness has a positive effect on the dimensions of trust in the organization and the manager, it has not seen any effect on the dimension of trust in colleagues. In addition to that, it was concluded that two dimensions of organizational trust, namely the trust in the manager and trust in the organization, had a positive effect on employees' job engagement.

Discussion - A significant effect of interaction justice has been observed on all dimensions of organizational trust. The clear and explicit expression of wishes and expectations of managers in their communication with their subordinates are important factors in the formation of

\section{Önerilen Atıf/Suggested Citation}

Öztürk, M., Vatansever, K. (2020). Örgütsel Adalet ve Örgütsel Güvenin İşe Adanmışlık Üzerindeki Etkilerinin Belirlenmesi: Alanya Belediyesi Çalışanları Üzerine Bir Araştırma, İşletme Araştırmaları Dergisi, 12 (4), 3613-3632. 
organizational trust of employees. It is observed that transactional justice affects trust in the organization and the manager, albeit at a low level. Therefore, it can be inferred that the process of making organizational decisions and declaration of the criteria which are used in this decision making process affect the trust of employees in their organizations and managers. Moreover, according to the research results; it can be interpreted that ensuring the trust in the organization and the manager is an important factor in establishing the engagement of the employees to the job.

\section{GİRIŞ}

Kurumlar ya da diğer bir ifadeyle örgütler içerisinde bulunduğu toplumun küçük bir yansımasıdır. Toplumu oluşturan bireyler; ihtiyaç ve isteklerini karşılamak, hayatlarını devam ettirmek, gelir sağlamak gibi ortak amaçlarla örgütlere katılmakta ve örgütsel faaliyetlerini sürdürmektedir.

Sosyal bilimler alanında yapılan çalışmalar, gerek örgüt fonksiyonlarının etkin kullanımında ve gerekse çalışanların kişisel doyumlarını sağlamada, örgütsel adaletin çok önemli bir yeri olduğuna vurgu yapmaktadır (Yıldırım, 2007: 256). Yapılan çalışmalar, örgütsel adalet algısının çalışanların tutum ve davranışlarında etkili olduğunu ortaya koymaktadır (Colquitt vd., 2001). Kurum içerisinde örgütsel adaletin tesis edildiğine inanan çalışanın, örgüte olan bağlılığı ve sadakati artacak, grup çalışması dinamiklerine daha fazla önem verecek, kurum amaç ve hedeflerini paylaşacak, çalışma motivasyonu ve dolayısıyla verimliliği ve üretkenliği artacaktır. Literatür incelendiğinde örgütsel adalet kavramının farklı bir çok değişken ile etkileşim halinde olduğu görülmektedir (Uğurlu ve Üstüner, 2011; İşçan ve Sayın, 2010; Gerome, 2008; Özmen vd., 2007; Gürpınar, 2006; Ertürk, 2003). Örgütsel hedeflerin gerçekleşmesini ve örgütsel fonksiyonların sağlıklı bir şekilde yerine getirilmesinde bir diğer önemli unsurda örgütsel güvendir. Güven duygusunun olmadığ1 ilişkilerin sürdürülebilir bir ilişki olmadığı (Asunakutlu, 2002: 2) ve tüm ilişkilerin temeli olduğu kabul edilmektedir (Gilbert ve Tang, 1998: 322). Örgüt içerisinde bilgi paylaşımının doğru yapılabilmesi, örgütsel iletişimin sağlıklı bir şekilde ilerlemesi, sorunların çözümü, yetki ve sorumlulukların paylaşılabilmesi için çalışanların, çalışma arkadaşlarına, yöneticilerine ve örgütlerine güvenmeleri temel bir koşul olarak karşımıza çıkmaktadır (Yazıcıoğlu, 2009: 237). Örgütlerde güven duygusunun artmasına bağlı olarak, çalışanlar arasında iletişim ağının arttığı, çalışan ve yöneticilerin kararlara katılımının sağlandığı, örgütsel verimliliğin arttığı ve kuralları ihlal etme oranın azaldığı belirtilmektedir (Aslan ve Özata, 2009: 104). Bununla birlikte, güven, örgüt ile çalışan arasındaki psikolojik sözleşmelerin ihlal edilip edilmemesiyle de ilgilidir. İhlal durumlarında çalışanların güven düzeylerinin düşeceği ve örgüte karşı sinik tutumlar sergileyebilecekleri işaret edilmektedir (Boylu ve Yıldırım, 2018: 34).

Günümüzde yetişmiş insan kaynağının, işletmeler için vazgeçilmez bir unsur olduğu bilinmektedir. Örgüt kültürüne uyum sağlamış, örgütü benimsemiş, kendini işine adayan çalışanları istihdam etmek ve bunların örgütlere olan bağlılığını sağlamak işletme verimliliği açısından önem arz etmektedir. Tükenmişliğin zıttı olarak kabul edilen işe adanmışlık (Bakker vd.,2008: 188), çalışanların iş yerlerindeki rolleri ile özdeşleşmeleri kendilerini fiziksel, bilişsel ve duyusal olarak rollerine adamalarını ifade etmektedir (Kahn, 1994: 694). Kendilerini işine adayan çalışanlar, genellikle hep daha iyisini yapma eğilimindedir. Çalışmak onları motive eder, diğer çalışanlara göre daha üretken olmakla birlikte işletmenin ve müşterilerin beklentilerini karşılama olasılıkları daha fazladır. Kendini işine adayan çalışanların pozitif tutumları, iyimserlikleri ve proaktif davranışları diğer çalışanların adanmışlıklarını da etkiler ve olumlu bir çalışma ortamı yaratır (Bakker vd., 2011:16). Doyasıyla kendini işe adayan çalışanların işletmelerine olan sadakatlerinin oluşmasında kurum için adalet ve güven duygusunun önemli bir belirleyici olduğu düşünülmektedir.

Toplumsal yaşamın her alanında olan adalet beklentisi, belki de en çok bireylerin çalıştıkları kurumlarda yoğunlaşmaktadır. Çalışanlar, bulundukları örgütlerde kendi konumları ile başkalarını kıyaslamakta, yöneticilerin kendileri ve diğer çalışanlarla iletişimi takip etmekte, örgütün elde etmiş olduğu kazanç ve kaynakların hangi ölçütlere göre nasıl dağıtıldığını izlemektedir (Eroğlu, 2014: 55-56). Bu değerlendirme ise çalışanların örgütlerine karşı güven duygusunun oluşmasında ve çalışanların kendilerini işlerine adamalarında etkili olmaktadır. Diğer bir ifadeyle; çalışanlarda örgütsel adalet algısının olması örgütlerine güven duymalarında (Chory ve Hubbel, 2008; Wong vd., 2006) ve kendilerini işlerine adamalarında (Erdirençelebi ve Karataş, 2019; Strom vd., 2014) önemli bir belirleyici olarak karşımıza çıkmaktadır.

Kurumların amaçlarını gerçekleştirebilmeleri ve toplumsal hayatta sürekliliklerini tesis edebilmeleri için kurum çalışanları açısından örgütsel adalet ve örgütsel güven önemli konulardır. Dolayısıyla çalışanların işe adanmışlık düzeyleri üzerinde etkileri vardır. Buradan hareketle çalışmanın temel amacı örgütsel aalet ve 


\section{M. Öztürk - K. Vatansever 12/4 (2020) 3613-3632}

örgütsel güvenin işe adanmışlık üzerindeki etkilerini belirlemek şeklinde ifade edilebilir. Örgütsel adaletin, güven üzerinde de etkileri olduğu kaçınılmazdır. Bu noktada da çalışmanın alt amacı, örgütsel adaletin örgütsel güven üzerindeki etkilerini belirlemek olarak ifade edilebilir.

Örgütsel adalet, örgütsel güven ve işe adanmışlık kavramları gerek tekil ve gerekse bir bütün olarak düşünüldüğünde, aralarındaki etkileşimlerin kurumların verimlilikleri ve üretkenlikleri üzerinde direkt etkilerinin olduğu söylenebilir. Dolayısıyla literatür ile benzer şekilde bu alanda yapılan çalışmaların çok büyük kısmının kar amacını faaliyetlerinin merkezine koyan özel işletmeler bünyesinde yürütüldüğü görülmektedir. Kar amacı gütmeyen kamu kurumlarında yapılan çalışmaların yetersiz olduğu gerçeği de çalışmanın önemini ifade etmektedir.

Çalışmada öncelikle örgütsel adalet, örgütsel güven ve işe adanmışlık ile ilgili literatüre ve hemen ardından ilgili değişkenlerin kendi aralarındaki ilişkilere yer verilmiştir. Sonraki bölümde çalışmanın metodolojisi ve yapılan analizler ayrıntılı bir şekilde açılanıp bulgulara yer verilmiştir. Son olarak elde edilen bulgular doğrultusunda sonuçlar ortaya konulup, mevcut literatüre yönelik tartışmalara ve ileriye yönelik perspektiflere değinilmiştir.

\section{Kavramsal Çerçeve}

\section{1. Örgütsel Adalet}

Arapça "adl" kökünden gelen adalet kavramı her şeyi yerli yerine koyma anlamına gelmekte (Kılınç, 2013; 30), Türk Dil Kurumu sözlüğünde ise hakka ve hukuka uygunluk, hakkı gözetme olarak tanımlanmaktadır (www.sozluk.gov.tr). İnsanlar, yetişkin olarak yaşamlarının büyük bir bölümünü bir örgütün üyesi olarak geçirmekte bu sebeple de adalet değerlendirmelerini en çok örgütsel yaşamlarında yapmaktadırlar (Beugre ve Baron, 2001). Temel olarak örgütsel faaliyetler sonucu elde edilen kazanç ve yararların, bireyler arasında hangi ölçütlere göre nasıl dağıtılacağını konu alan örgütsel adalet kavramı ilk olarak 1987 yılında Academy of Management Review dergisinde Greenberg tarafından yayınlanan "A Taxonomy of Organizational Justice Theories" adlı makalesinde kullanılmıştır (Küçükeşmen, 2015). Bu çalışmadan sonra örgütsel adalet kavramı birçok araştırmacının dikkatini çekmiştir.

Örgütsel adalet kavramı temelde Adams'ın (1965) eşitlik teorisine dayanmaktadır (Greenberg, 1990; Cropanzo vd., 2001; Altıntaş, 2006; Cihangiroğlu ve Yılmaz, 2010; Ay ve Koç, 2014). Bu teoriye göre bireyler iş çıktılarıyla kendileriyle benzer konumda olanların iş çıktılarını karşılaştırırlar. Örgüte kattıklarının karşılı̆̆ında edindikleri kazanımların oranına bakıp kendisiyle benzer konumda olanların oranıla karşılaştırdıklarında örgütsel adalet ile ilgili bir değerlendirme yapmış olurlar. Temelde örgütsel adalet bu değerlendirme sonucunda çalışanların iş yerindeki uygulamalara yönelik algılarını ifade eden bir kavramdır (Greenberg, 1990: 400). Moorman'a (1991) göre örgütsel adalet; çalışma alanlarıyla ilgili adaleti tanımlayan bir kavram olup, çalışanlara iş yaşamlarında adil bir şekilde davranılıp davranılmadığı ile ilgilidir. Lamrakis ve arkadaşları (2018) örgütsel adaleti; örgütlerin çalışanlara yönelik adil ve etik davranışlarını ifade eden bir kavram olarak tanımlamışlardır. Cropanzano ve arkadaşları (2007) da örgütsel adaleti diğer tanımlarla benzer olarak; kişilerin yönetim davranışlarının etik olup olmamasına yönelik kişisel bir değerlendirme olarak ifade etmişlerdir. Yıldırım'a (2007) göre örgütsel adalet örgütlerde ortaya çıkan ödül ve cezaların nasıl dağıtılacağına dair kural ve normlar iken, İçerli'ye (2010) göre ise örgütsel adalet; örgüt içerisinde ücretlendirmenin, verilecek ödüllerin, yapılacak terfilerin nasıl yapılacağı ve buna nasıl karar verildiği, alınan bu kararların çalışanlarla nasıl paylaşıldığı ve çalışanların bu paylaşımı algılama şekli olarak tanımlanmaktadır.

Literatür incelemesi yapıldığında örgütsel adalet ile ilgili ilk yapılan çalışmalarda örgütsel adalet; dağıtım adaleti ve prosedürel adalet olmak üzere 2 boyutta ele alınırken (Greenberg, 1990; Moorman, 1991: 845; Lam vd., 2002: 1; Fox vd., 2001: 292) son yapılan çalışmalar da ise dağıtım adaleti ve prosedürel adalet ile birlikte etkileşim adaletinin de üçüncü bir boyut olarak ele alındığı görülmektedir (İyigün, 2012: 57; Beugr, 2001: 325; Cropanzano vd., 2007: 37-38; Saunders ve Thornhill, 2004: 497). Bu bölümde örgütsel adaletin boyutları olarak dağıtım adaleti (distributive justice), işlem adaleti (procedure justice) ve etkileşim adaleti (interactional justice) ele alınacaktır.

-Dağıtım Adaleti (Distributive Justice): Dağıtım adaleti, bireylerin maaş artışları, promosyonlar, örgüt içerisindeki iş paylaşımları (Scandura, 1999) gibi örgütsel çıktılardan aldıkları sonuçların adil olup olmadığı 


\section{M. Öztürk - K. Vatansever 12/4 (2020) 3613-3632}

algısı olarak tanımlanmaktadır (Adams, 1965; Greenberg, 1990 ;Olkkonen ve Lipponen, 2004: 409; Cropanzo vd., 2001: 6; Fox vd., 2001: 294). Diğer bir ifadeyle dağıtım adaleti; "çalışanlar aldıkları ücretin, terfilerin, ödüllerin" adil olup olmadığı sorusuna cevap arar (Yelboğa, 2012: 172). Dağıtım adaleti ile ilgili yapılan çalışmalar temelde Adams'ın eşitlik teorisine dayanmaktadır (Goblit, 2011; Thorn, 2010). Adams teorisinde; çalışanların örgütlere eğitim, emek ve tecrübe gibi bir takım girdiler sunduklarını, bu girdilerin karşılığında ise maaş, terfi gibi çıktılar beklediklerini ifade etmektedir. Çalışanların sundukları girdilere karşılık olarak elde ettikleri çıktıları değerlendirdiklerinde dağılımın adil olduğu sonucuna varmaları memnuniyetin ortaya çıkmasına, sonucun adil olmadığını düşünmeleri ise memnuniyetsizliğin oluşmasına yol açmaktadır (Adams, 1965). Dağıtım adaleti tüm çalışanlara eşit şekilde muamele edilip edilmemesiyle ilgili olup, örgütsel çıktıların dağılımının farklılaşmasıyla veya diğer bir deyişle çalışanların paylarını adil olarak alıp almadıklarıyla ilgili bir kavramdır (Cropanzano vd., 2007: 37). Örgüt içerisindeki kazanımların adil dağılmadığı durumlarda çalışanların iş performansında düşüş ve iş kalitesinde azalma (Pfeffer ve Langton, 1993: 384-385) gibi bireylerin duygusal, bilişsel ve davranışsal durumlarını olumsuz yönde etkileyecektir (Cohen vd., 2001: 280). Colquitt ve arkadaşları (2001) da yaptıkları meta-analiz çalışmasında dağıtım adaletinin; örgütsel güven, iş tatmini, iş performansı ve örgütsel bağlılık gibi birçok unsur üzerinde etkili olduğunu ifade etmişlerdir.

-İ̧lem Adaleti (Procedural Justice) : İşlem adaleti; çalışanlar için örgütsel çıktıların yanında bu çıktıların dağılımına hangi süreçlerle nasıl ulaşıldığının öneminin anlaşılması sonucu ortaya çıkmıştır (Nowakowski ve Conlon, 2005: 6). Diğer bir ifadeyle işlem adaleti; örgütte alınan kararların nasıl alındığına dair süreçleri inceleyen bir kavramdır (Olkkonen ve Lipponen, 2004:204; Cropanzo vd.,2001: 165; Colquitt; 2004: 633). Dağıtım adaleti daha çok sonuçların ne kadar adil olduğu ile ilgiliyken, işlemsel adalet ise çalışanların karar alma süreçlerine katılmaları ve süreçlerin ne kadar adil olup olmadığıyla ilgilenmektedir (Moon vd., 2008: 85). Yapılan çalışmalar; sonuçlara ulaşmadaki süreçlerin kaynakların dağıtılmasında adil olunmasından daha önemli olduğunu ortaya koymaktadır (Proost vd., 2013: 19). Bireylerin çalıştıkları kurumlarıyla ilgili adalet algılarında sadece elde ettikleri kazanımlar etkili olmamakta bununla birlikte, kimin neyi, nasıl, ne kadar alacağı ve buna nasıl karar verileceği de adalet algılarının oluşmasında önemli ölçüde etki etmektedir (İyigün, 2012: 58). İşlem adaleti ayrıca; kurumun çalışanların süreçlerin işleyişiyle ilgili bilgi edinme haklarının olduğuna saygı duyduğunun da bir göstergesidir (Konovsky ve Pugh, 1994: 658). İşlemsel adaletin olması; çalışanların kurumsal kural ve prosedürleri kabullenmeleri için bir gereklilik olarak görülmektedir. Eğer sonuçlara giden süreçler çalışanlar tarafından adil olarak algılanıyorsa; çalışanlar kurumun çıkarları için en iyi şekilde çalışacak, kuruma en üst düzeyde bağlı kalacaklar, liderlerini ve kurumlarını yarı yolda bırakmayacaklardır (Cropanzo vd., 2007: 39). Çalışanların süreçlerle ilgili bilgi sahibi olması onların örgüt tarafından aldatılmadıkları inancına sahip olmalarını da sağlayacaktır (Saunders ve Thornhill, 2004: 498). İnsanlar sonuçların ortaya çıkmasındaki süreçlerin adil olmadıklarına inandıklarında ise; örgütlerine daha az bağlı olacaklar, daha fazla hırsızlık yapacaklar, daha az performans gösterecekler ve iş değiştirme eğilimleri de daha fazla olacaktır (Yıldırım, 2007: 258).

-Etkileşim Adaleti (Interactional Justice) : Çalışanlar ve yöneticiler arasında örgütsel adaletin sağlanmasında maddi kaynakların yetersiz kalması sebebiyle örgütsel adaletin sosyo-psikolojik boyutu olan etkileşim adaleti ortaya çıkmıştır (Yeniçeri vd., 2009:86). Örgütsel adaletin üçüncü bir boyutu olarak eklenen etkileşim adaletin temelini, örgüt yöneticilerinin karar alma aşamalarındaki tutum ve davranışlarının (Olkonnen ve Lipponen, 2006: 204) da örgütsel adalet üzerinde etkili olabileceği düşüncesi oluşturmaktadır (Greenberg, 1990: 411). Yöneticilerin, örgüt içerisinde çalışanlar ile kurdukları iletişim şekli de çalışanların örgütsel adalet algılarının belirlemede etkili olmaktadır. Yapılan araştırmalarda çalışanlar; dürüstlük, nezaket, düzenli bilgi alışverişinde bulunma düşüncelere sayg1 gösterme gibi davranışlarında örgütsel adaletin bir göstergesi olduğunu ortaya koymaktadır (Greenberg, 1990: 411). Dolayısıyla etkileşim adaleti örgütsel uygulamaların kişilerarası yönünde, özellikle örgüt yöneticilerinin çalışanlarla arasındaki iletişime ve onların davranış şekillerine odaklanmaktadır (Cohen vd., 2001: 279). Çalışanlar aynı zamanda örgütsel kararların nasıl alındığını hakkında da bilgi sahibi olmak ve kendilerini açıklama yapılmasını da beklemektedir. Etkileşim adaleti; örgütte uygulanan prosedürlerin neden uygulandığına ve örgütsel çıktıların hangi şekilde dağıtıldığına dair çalışanlara yapılan açıklamalara odaklanmaktadır (Colquitt vd., 2001: 427). Örgütteki karar vericiler uygulanan prosedürler hakkında çalışanlara yeterli bilgi vermiyor, nezaket dışı davranışlarda bulunuyor ve iletişim kanallarını kapatıyorlarsa çalışanlar da örgütsel adalet algıları azalacaktır (Köksal, 2016: 22). 


\section{2. Örgütsel Güven}

Birçok araştırmacı ve klasik felsefe düşünürü sosyal hayat içerisinde ortaya çıan çatışmaların ve kaosların önlenmesinde güven kavramının etkisi üzerinde durmuş ve sosyal bilimler alanında güven üzerinde birçok çalışma yaparak farklı tanımlamalar ortaya koymuştur (Yıldırım, 2014). Cook ve Wall (1980)'a göre güven; bir kişinin karşı tarafın davranışları hakkında olumlu bir yargıya sahip olması ve karşı tarafa inanma arzusudur (Cook ve Wall, 1980: 39). Zand (1972)' a göre güven yalnızca bir his ya da duygu değil aynı zamanda kişinin diğer kişiye olan güveninin bilinçli olarak düzenlenmesidir (Zand, 1972: 230). Mcallister (1995)'e göre güven ise; kişinin diğer bireylerin söz, eylem ve kararlarından emin olması ve bu doğrultu da hareket etmek istemesidir (Mcallister, 1995: 25). Güven bireysel ve örgütsel düzeyde oluşur. Fakat kişiye duyulan güven ile örgüte duyulan güven arasında farklılık vardır (Doney ve Cannon, 1997: 35). Bireylerin birbirleriyle olan ilişkilerine ve deneyimlerine dayalı olarak ortaya çıan güven "bireysel güven" olarak değerlendirilirken, kurumsal ilişkiler sonucunda ortaya çıkan güven ise "örgütsel güven" bir diğer ifadeyle şahsi olmayan güven olarak tanımlanmaktadır (Bachmann, 2002: 7). Gilbert ve Tang (1998)'a göre örgütsel güven; işverenin çalışana karşı vermiş olduğu taahhütleri yerine getireceğine dair iş görende oluşan güven ve destek hissidir (Gilbert ve Tang, 1998: 322). Bir diğer tanımda ise örgütsel güven; örgütsel hedefleri içselleştirmeyi, işbirliğini geliştirmeyi, örgüt içerisinde ortak beklentilere uygun olarak davranış sergilemeyi sağlayan bir unsur olarak tanımlanmaktadır (Yıldırım, 2014). Literatür incelemesi yapıldığında örgütsel güvenin yaygın olarak; örgüte olan güven, yöneticiye güven ve iş arkadaşlarına güven olmak üzere üç boyutta ele alındığı görülmektedir (Adams, 2004; Dietz ve Hartog, 2006; Arslan, 2009; Nedkovski vd., 2017).

-Yöneticiye Güven: Örgüt yöneticileri ve profesyonelleri için çalışanların onlara olan güvenlerini geliştirmek ve bu güveni sürdürmek özellikle büyük önem taşımaktadır (McAllister, 1995: 24). Örgüt yöneticileri, iş görenlerin örgüte olan güvenlerinin oluşmasında, iş görenlerle iyi ilişkiler kurma konusunda (Yolaç, 2011: 64) ve çalışanların işlerinden duydukları tatmin düzeyinde önemli bir etkiye sahiptir (Koç ve Yazıcıŏlu, 2011: 48). Öyle ki örgüt yöneticileri için en etkili organizasyon aracı "güven" olarak görülmekte ve örgüt içerisinde güven ilişkisi olmadan en kusursuz şekilde oluşturulmuş planların bile başarıya ulaşamayacağı bilinmektedir (Culbert ve McDonough, 1986: 171). Bu sebeple örgütsel güvenin sağlanmasında çalışanların yöneticilere güvenmesi önemli bir koşul olarak karşımıza çıkmaktadır. Aksi durumlarda çalışanların örgütün lehine olabilecek durum ve süreçlerde sessizlik tutumları sergileyebileceği düşünülmektedir (Yıldırım, 2019: 361).

-Çalışma Arkadaşlarına Güven: Çalışma arkadaşlarına güven; bir çalışanın çalışma arkadaşlarının yetkinliğine güvenmesi, onların adil, etik davranacağına inanması ve iş arkadaşlarının söz ve eylemlerine güvenmesini ifade etmektedir (Ferrers vd., 2004: 610). Çalışanlar, üyesi oldukları örgütlerde çalışma arkadaşlarıyla etkileşim içerisinde olmakta, kimi zaman özel hayatlarıyla ilgili bilgiler paylaşmakta ve iş akışının sağlanması için iletişim halinde olmaktadır. Örgütsel üyeliğin ve örgüt içi ilişkilerinin devam etmesi ve "biz" ruhunun oluşabilmesinin en önemli koşulu ise güvendir. Çalışanlar arası güvenin olmadığı koşullarda; ortak amaçlar için hareket edilmesi ve gayret gösterilmesi mümkün olmayacaktır (Büte, 2011: 177). Çalışanların, çalışma arkadaşlarına güvenmesi herhangi bir endişe duymasına gerek kalmayacağından örgütsel hedefler doğrultusunda çalışmasını kolaylaştırırken, çalışma arkadaşları arasında oluşan güvensizlik ise çalışma ortamında oluşan risk sebebiyle çalışanların gergin olmasına sebep olacaktır (Dirks ve Ferrin, 2001: 456).

-Örgüte Güven: Son y1llarda örgüt bilimciler tarafından yoğun bir şekilde araştırılan örgüte güven kavramı (Koçak ve Koç, 2018); bir bütün olarak örgütün genelini ilgilendiren konular da çalışanların örgüte olan güvenini ifade etmektedir (Yıldırım, 2014). Çalışanların, örgüt içerisindeki haklarının korunacağına, adil ve etik davranılacağına dair örgütlerine duydukları güvendir (Topaloğlu, 2010: 44). Örgüte olan güven boyutu; kişiler arası ilişkilerden farklı olarak direkt olarak kurumsal kimliğe olan güvenle alakalıdır (Kaneshiro, 2008: 39).

\section{3. İşe Adanmışlık}

Örgütsel davranış alanında literatür incelemesi yapıldığında İngilizce karşılığı "job engagement" olan kavramın Türkçe 'de işe adanmışlık, çalışmaya tutkunluk, işe cezbolma, işe bağlanma gibi terimlerle karşılık bulduğu görülmektedir. Genel itibariyle psikolojik bozukluklara odaklanan klinik psikolojiye tepki olarak ortaya çıkan ve insanların güçlü yönlerini ve iyi oluş hallerini geliştiren faktörleri inceleyen pozitif psikoloji'nin (Carr, 2016: 9) örgütlerdeki uygulama alanı olarak da pozitif örgütsel davranış ortaya çıkmıştır. Pozitif örgütsel davranış; pozitif psikoloji kapasitesinin kullanılarak iş performansının geliştirilmesini 


\section{M. Öztürk - K. Vatansever 12/4 (2020) 3613-3632}

hedefler (Luthans vd, 2004: 46). Bu anlamda tükenmişlik kavramının zıttı olarak ortaya çıkan işe adanmışlık (Keleş, 2014: 98); çalışanların kendilerini işlerine fiziksel, bilişsel ve duyusal olarak adamaları olarak tanımlanmıştır (Kahn, 1990: 694). Bir başka tanıma göre ise işe adanmışlık; enerji dolu bir şekilde çalışanın işiyle bütünleşmesini (Hallberg ve Schaufeli, 2006), çalışma ortamında çalışanların işleriyle ilgili zaman ve çaba harcamaya istekli olmalarını, bütünüyle kendi görevlerine konsantre olmalarını ifade etmektedir (Bakker vd., 2011). İşe adanmışlık kavramıyla ilgili birçok tanımlama olsa da, genel olarak çalışanların işlerine karşı olumlu tutumları ile fiziksel ve bilişsel enerjilerini işlerine yansıtarak işleriyle bütünleşmelerine ortak vurgu yapıldığı görülmektedir. İşe adanmışlık; olumlu, tatmin edici ve işle ilgili zihin durumunu da kapsayan çok boyutlu bir yapıdır. Bu boyutlar: dinçlik (vigor), adanmışlık (dedication) ve yoğunlaşma (absorption) olarak sınıflandırılmıştır (Gonzalez-Roma vd., 2006; Bakker vd., 2008).

Dinçlik (vigor) kavramı; çalışanın çalışma esnasında yüksek düzeyde enerjiye ve zihinsel esnekliğe sahip olmasını ifade eder. Dinçlik, bireyin işi için çaba göstermesini ve zorluklar karşısında sabretmesini ifade eden bir kavramdır (Bakker ve Demerouti, 2008; Bakker vd., 2008; González-Romá vd., 2006; Bakker ve Bal, 2010). Çalışırken dinçlik hissine sahip olan bireyin işine karşı motive olması onun güçlüklerin üstesinden kolaylıkla gelmesini sağlamaktadır. Adanmışlık (dedication) boyutu; çalışanın işine güçlü bir aidiyet hissetmesi ve işin çalışanda önem, coşku, gurur ve meydana okuma duygusu olarak açıklanmaktadır (Jenaro vd., 2011: 867). Kendilerini çalışmaya adayan iş görenler, işlerinin bir amacının olduğunu, mücadele gerektirdiğini, işin ilgi çeken bir yönünün olduğunu düşünür ve işleriyle gurur duyarlar (Çalışkan, 2014: 371). İşe adanmışlığın son boyutu olan yoğunlaşma ise çalışanın işine sarılması ve çalışırken zamanın geçtiğinin farkına varmaması olarak ifade edilmektedir. Yoğunlaşma boyutunda çalışan tam bir konsatrasyon ile işine dalar ve bundan mutluluk duyar (Simpson, 2009:47).

\subsection{Değişkenler Arası İlişkiler}

\subsection{1. Örgütsel Adalet ve Örgütsel Güven İlişkisi}

Literatür incelemesi yapıldığında örgütsel adalet ile ilgili yapılan birçok araştırma örgütsel adaletin, örgütsel güven üzerinde etkili olduğunu hem yabancı çalışmalarda (Konovsky ve Pugh, 1994; Konovsky ve Cropanzano, 1991; Aryee vd., 2002; Wong vd., 2006; Farooq ve Farooq, 2014) hem de yerli çalışmalarda (Arslan ve Yavuz, 2019; Aktuğ, 2016; Sakallı, 2015; Akyel, 2014; Polat, 2007) ortaya konulmuştur. Bu çalışmalara bakıldığında; örgütsel adaletin boyutları (dağıtım adaleti, işlemsel adalet, etkileşim adaleti) ile örgütsel güvenin boyutları arasında (yöneticiye güven, çalışma arkadaşına güven, örgüte güven) anlamlı ilişkiler olduğu görülmüştür. Seifert ve arkadaşlarının (2013) yaptıkları çalışmada; etkileşimsel adalet ile yöneticiye güven arasında, örgütsel adaletin tüm alt boyutları ile de örgüte güven arasında güçlü ilişkiler olduğu ortaya konulmuştur. Alexander ve Ruderman (1987) yaptıkları çalışmada çalışanların işlemsel ve dağıtımsal adalet algıları ile yöneticilerine duydukları güven arasında pozitif yönlü bir ilişki olduğu sonucuna ulaşmışlardır. Abr Rowa ve arkadaşları ise (2013) yaptıkları çalı̧̧mada etkileşimsel adalet ve yöneticiye güven arasında, dağıtımsal ve prosedürel adalet ile de örgüt güven arasında anlamı ve pozitif yönlü ilişkiler olduğu sonucuna ulaşmışlardır. Wong ve arkadaşları (2006) yaptıkları çalışmada; etkileşim adaletinin yöneticiye güven ile dağıtım adaleti ve prosedürel adaletin ise örgüte güven ile ilişki içinde olduğu tespit etmişlerdir. Bir başka çalışmada ise dağıtımsal adaletin yöneticiye olan güven üzerinde, işlemsel adaletin ise yöneticiyle birlikte örgüte olan güven üzerinde önemli bir belirleyici olduğu sonucuna ulaşılmıştır (Hubbel ve Chory-Assad, 2005). Yerli literatürde de örgütsel adalet algılarıyla ile örgütsel güven arasındaki ilişkileri araştıran birçok çalışma mevcuttur. Polat (2007) çalışmasında; örgütsel adaletim tüm boyutlarının yöneticiye güven ve örgüte güven üzerinde etkili olduğunu ortaya koymuştur. Sakallı (2015) yaptığı çalışmada da benzer olarak örgütsel adaletin tüm boyutları ile örgütsel güvenin tüm boyutları arasında anlamlı ilişkiler olduğu görülmüştür. Akyel (2014) hazırlamış olduğu çalışmada; örgütsel adaletin alt boyutları ile örgütsel güvenin alt boyutları arasında pozitif yönlü anlamlı ilişkilerin olduğu sonucuna ulaşmıştır.

\subsection{2. Örgütsel Adalet ve İşe Adanmışlık İlişkisi}

Adalet duygusu, bireylerin birçok davranışı üzerinde etkili olduğu gibi işlerine karşı motivasyonlarını da önemli ölçüde etkileyecektir. Örgüt içerisinde; adaletsizliğe uğrayan çalışan kendini işine veremeyecek, yaptığı işten zevk almayacaktır. Literatür de yapılan araştırmalar da örgütsel adaletin çalışanların işe adanmışlıkları üzerinde etkili olduğunu göstermektedir. 210 çalışan üzerine yapılan bir araştırmada örgütsel adaletin tüm boyutlarının işe adanmışlık üzerinde etkili olduğu ortaya konulmuştur (Ghosh vd., 2014). 


\section{M. Öztürk - K. Vatansever 12/4 (2020) 3613-3632}

Kore'de 266 çalışan üzerine yapılan araştırmada örgütsel adaletin işe adanmışlık üzerinde anlamlı ve pozitif yönlü bir ilişkisinin olduğu tespit edimiştir (Park vd., 2016). Japonya'da 243 çalışan üzerine yapılan bir araştırma da ise etkileşim adaleti ve işlem adaletinin çalışanların işe adanmışlığı ile anlamlı ve pozitif bir ilişkisinin olduğu sonucuna ulaşılmıştır ulaşılmıştır (Inoue vd., 2010). Online anket yöntemliyle 348 çalışan üzerinde yapılan bir başka araştırmada ise örgütsel adalet ve işe adanmışlık arasında güçlü bir ilişkinin olduğu tespit edilmiştir (Strom vd., 2014). Hindistan'da 296 çalışan üzerine yapılan bir başka araştırmada bu bulguları destekler niteliktedir. Araştırma sonuçları örgütsel adalet ve işe adanmışlık arasında güçlü ve pozitif yönlü bir ilişkinin olduğunu göstermiştir göstermiştir (Sharma ve Yadav, 2018). Örgütsel adaletin işlem adaleti boyutu ve işe adanmışlık arasındaki ilişkiyi belirlemeye yönelik yapılan bir başka araştırmada işlem adaletinin işe adanmışlık üzerinde önemli düzeyde etkisinin olduğu belirtilmiştir (Li vd., 2010). Yerli literatürde ki çalışmalarda yabancı literatürdeki sonuçları destekler niteliktedir. Konya'da 400 banka çalışanı üzerine yapılan araştırma da çalışanların örgütsel adalet algılarının işe adanmışlık düzeylerini artırdığı sonucuna ulaşılmıştır (Erdirençelebi ve Karataş, 2019). Öğretmenlerin örgütsel adalet algıları ile örgütsel adanmışlıkları arasındaki ilişkiyi inceleyen bir başka çalışmada, örgütsel adaletin tüm boyutları ile örgütsel adanmışlık arasında anlamlı ve pozitif yönlü ilişkiler olduğu tespit edilmiştir (Babaoğlan ve Ertürk, 2013). 181 akademisyen üzerinde yapılan bir başka araştırmada ise yapılan istatistiki analizler sonucunda örgütsel adaletin işe adanmışlığı anlamlı bir şekilde etkilediği sonucuna ulaşılmıştır (Demirhan ve Karaman, 2015).

\subsection{3. Örgütsel Güven ve İşe Adanmışlık İlişkisi}

Hem yerli hem de uluslararası literatürde yapılan çalışmalar örgütsel güven ve işe adanmışlık arasında anlamlı ilişkiler olduğunu göstermektedir. 715 banka çalışanı üzerine yapılan araştırma da örgütsel güven ve işe adanmışlık arasında güçlü ve pozitif bir ilişkinin olduğu sonucuna ulaşılmıştır (Ugwu vd., 2014). 428 çalışan üzerinde yapılan bir diğer çalışma da benzer şekilde örgütsel güven ve işe adanmışlık arasında pozitif yönlü bir ilişkinin olduğu tespit edilmiştir (Lin, 2010). Örgütsel güvenin bir boyutu olan yöneticiye güven ile işe adanmışlık arasındaki ilişkinin araştırma sorularından birini oluşturduğu bir diğer çalışmada bu iki değişken arasında pozitif yönlü bir ilişkinin olduğu ifade edilmiştir (Engelbrecht vd., 2014). Örgütsel güven ve işe adanmışlık arasındaki ilişkinin anlamlı ve pozitif yönde olduğu sonuçlarına Türkiye'de yapılan çalışmalarda da ortaya konulmuştur. Örneklemin Türkiye'deki 559 ilkokul öğretmenin oluştuğu çalışmada yapılan istatistiksel analiz sonucunda örgütsel güven ve işe adanmışlık arasında yüksek düzeyde ve anlamlı bir ilişki olduğu sonucuna ulaşılmıştır (Gülbahar, 2017). Farklı sektörlerde çalışan 412 iş gören üzerine yapılan araştırma da örgüte duyulan güvenin işe adanmışlığı artırdığı sonucuna ulaşılmıştır (Arabacı, 2012). İstanbul'da faaliyet gösteren 1180 yönetici pozisyonundaki çalışan üzerine yapılan çalışmada da örgütsel güvenin bir boyutu olan yöneticiye güven boyutu ile işe adanmışlığın anlamlı ve pozitif yönlü bir ilişkisinin olduğu ortaya konulmuştur (Özdemir, 2015).

\section{Yöntem}

Araştırmada nicel araştırma desenlerinden tarama modeli kullanılmıştır. Tarama araştırma modelleri, kişilerin belirli konulardaki tutum, inanç, görüş, davranış, beklenti ve özelliklerini anketler yardımıyla tespit etmeye çalışan araştırma türüdür (Gürbüz ve Şahin, 2018: 105). Araştırmada yer alan değişkenler arası ilişkinin analiz edilmesi için PLS-SEM (kısmi en küçük kareler yapısal eşitlik modeli) kullanılmıştır. Bu kapsamda kısmi en küçük kareler ölçüm modeliyle ölçeklerin güvenilirlik, geçerlilik ve doğrulayıcı faktör analizleri yapılmıştır. Sonrasında ise yol analizi yapılarak hipotez testlerine yer verilmiştir. Verilerin analizinde SmartPLS 3.2.9 paket programı kullanılmıştır.

\subsection{Araştırmanın Amacı ve Modeli}

Bu araştırma Alanya Belediyesi çalışanlarının Örgütsel Adalet ve Örgütsel Güven'e yönelik tutumlarının İşe Adanmışlık üzerindeki etkilerini belirlemek amacıyla yapılmıştır. Çalışmanın bir diğer amacı da örgütsel adalet davranışının örgütsel güven üzerindeki etkilerini belirlemektir. 


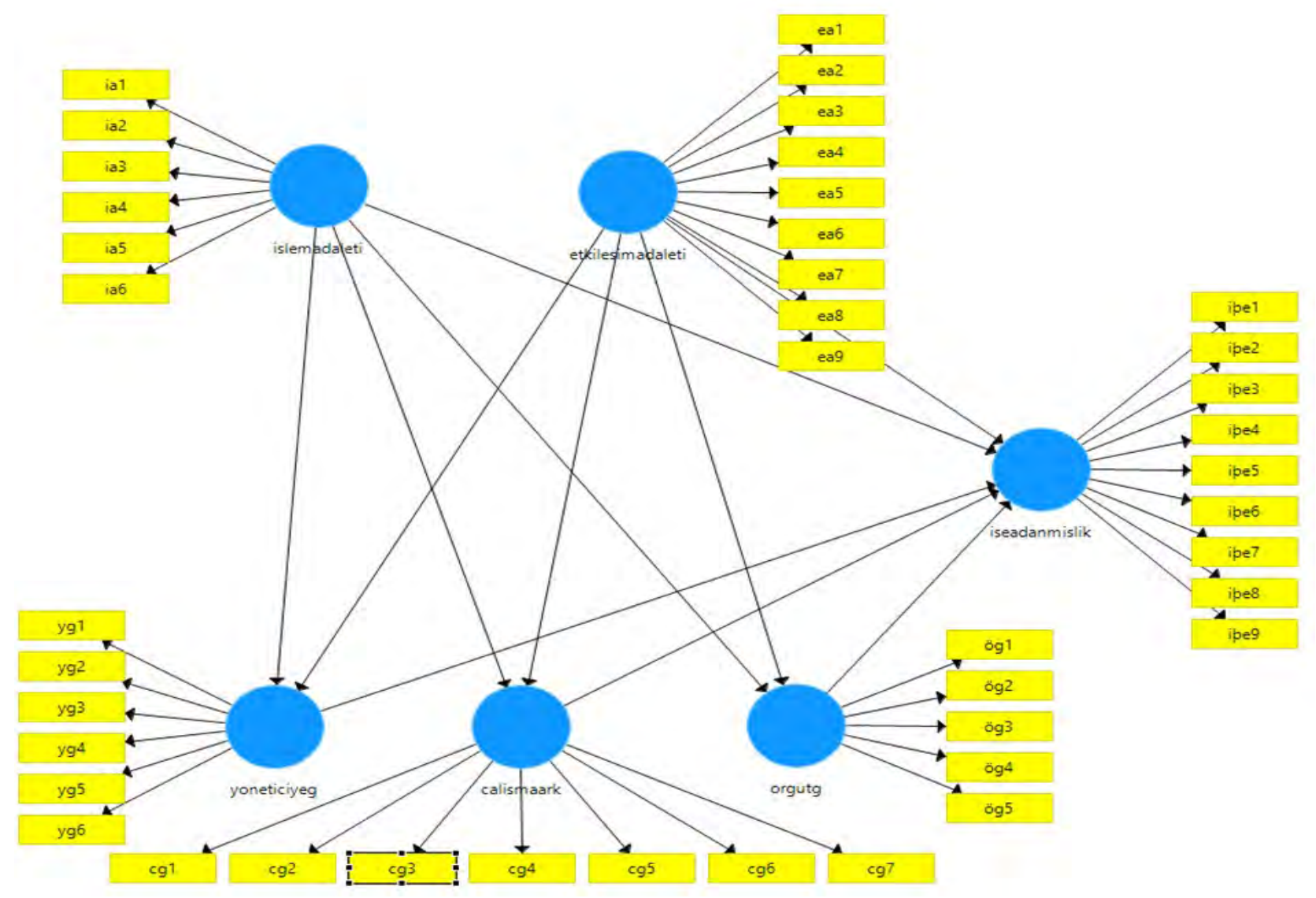

Şekil 1: Araştırma Modeli

\subsection{Araştırmanın Hipotezleri}

$\mathrm{H}_{1}$ : Etkileşim adaleti işe adanmışlığı pozitif yönde etkiler.

$\mathrm{H}_{2}$ : Etkileşim adaleti örgüte güveni pozitif yönde etkiler.

$\mathrm{H}_{3}$ : Etkileşim adaleti çalışma arkadaşına güveni pozitif yönde etkiler.

$\mathrm{H}_{4}$ : Etkileşim adaleti yöneticiye güveni pozitif yönde etkiler.

H5: İşlem adaleti işe adanmışlığ1 pozitif yönde etkiler.

H6: İşlem adaleti örgüte güveni pozitif yönde etkiler.

H7: İşlem adaleti çalışma arkadaşına güveni pozitif yönde etkiler.

Hs: İşlem adaleti yöneticiye güveni pozitif yönde etkiler.

H9: Örgüte güven işe adanmışlığı pozitif yönde etkiler.

H1o: Çalışma arkadaşına güven işe adanmışlığı pozitif yönde etkiler.

H11: Yöneticiye güven işe adanmışlı̆̆ı pozitif yönde etkiler.

\subsection{Araştırmanın Veri Toplama Araçları}

Katılımcılara, kapalı uçlu sorulardan oluşan bir anket formu uygulanmış ve 5'li Likert Ölçeği kullanılan ifadelere cevap vermeleri istenmiştir. Anket formu iki bölümden ve toplam 48 sorudan oluşmaktadır. İlk bölümde çalışanların cinsiyetini, yaşını, medeni durumunu, kurumda çalışma süresini, eğitim durumunu ve çalışma statülerine yönelik 6 demografik soru yöneltilmiştir. Sonrasında ise örgütsel adalet, örgütsel güven ve işe adanmışlı düzeylerini ölçmeye yönelik toplam 42 soru sorulmuştur. 
Örgütsel Adalet Ölçeği: Katılımcıların örgütsel adalet algılarını ölçmek için Niehoff ve Moorman (1993)'ın geliştirmirmiş olduğu Örgütsel Adalet ölçeğinin İşlem Adaleti ve Etkileşim Adaleti boyutları kullanılmıştır. Kamu kurumlarında aynı statüde çalışan kişiler arasında bir maaş ve gelir farkı bulunmamasından dolayı ücret, maaş, pirim gibi kaynakların nasıl dağıtıldığını ölçmekte kullanılan Dağıtım Adaleti boyutu anket formuna dâhil edilmemiştir. İşlem Adaleti boyutu 6, Etkileşim Adaleti boyutu 9 önerme ile ölçülmektedir.

Örgütsel Güven Ölçeği: Katılımcıların Örgütsel Güven algılarını ölçmek için Adams (2004)'ın geliştirdiği Örgütsel Güven Ölçeği kullanılmıştır. Ölçek üç boyuttan oluşmaktadır. Yöneticiye Güven boyutu 6, Çalışma Arkadaşlarına Güven boyutu 7 ve Örgüte Güven boyutu 5 önerme ile ölçülmektedir.

İşe Adanmışlık Ölçeği: Çalışanların İşe Adanmışlık düzeylerini ölçmek için Schaufeli vd. (2006) tarafından geliştirilen ve Özkalp ve Meydan (2015) tarafından Türkçe'ye çevrilen 9 önermeden oluşan İşe Adanmışlık Ölçeğinin tek boyutlu formu kullanılmıştır.

\subsection{Araştırmanın Evreni ve Örneklemi}

Araştırmanın evrenini Alanya Belediyesi çalışanları oluşturmaktadır. Alanya Belidiyesi'nin 2019 yılı faaliyet raporuna göre 275 Memur, 286 Daimi İşçi ve 30 Sözleşmeli Personel olmak üzere toplam çalışan sayısı 591'dir. Dolayısıyla araştırmanın evreni 591 kişiden oluşmaktadır (Alanya Belediyesi Faaliyet Raporu, 2019: 28). Çalışanların sürekli olarak tek bir merkezde yer almamaları nedeniyle tamamına ulaşma imkanı bulunmamaktadır. Bu nedenle çalışmada kolayda örnekleme yöntemi tercih edilmiştir. Kolayda örneklemede araştırmacı ihtiyaç duyduğu örnekleme ulaşıncaya kadar en kolay yol ile ulaşılabilir deneklerden veri toplamaya çalışır (Gürbüz ve Şahin, 2018:132).

Anketler Alanya Belediyesi AR-GE sorumlusuna 1 Aralık 2019 tarihinde verilmiş ve onun nezaretinde cevaplanan anketler 28 Aralık 2019 tarihinde teslim alınmıştır. Eksik ve hatalı anketler çıarıldıktan sonar gönüllülük esasına dayalı toplam 219 anket formu araştırmanın analizlerinde kullanılmıştır. Araştırma evreninin 591 kişiden oluşması ve 0,05 güven aralığında 219 kişilik bir örneklemin evreni yeterince temsil ettiği söylenebilir. (Yazıcıŏlu ve Erdoğan, 2004: 50)

\subsection{Verilerin Analizi}

\subsubsection{Güvenilirlik Analizleri}

Modelin test edilmesinden önce araştırmada kullanılan ölçeklerin güvenilirlik ve geçerlilik analizleri yapılmıştır. Bu kapsamda, iç tutarlılık güvenilirliği, birleşme geçerliliği ve ayrışma geçerliliği sonuçları incelenmiştir. İç tutarlılık güvenirliğini değerlendirmek için Cronbach Alfa ve Composite Reliability katsayılarına bakılmıştır. Birleşme geçerliliğinin tespitinde ise faktör yükleriyle açılanan Average Variance Extracted (AVE) değerleri kullanılmıştır. Aşağıdaki tabloda; araştırmadaki değişkenlerin faktör yükleri, iç tutarlılık güvenirliği ve birleşme geçerliliği sonuçları yer almaktadır.

Tablo 1: Ölçüm Modeli Sonuçları

\begin{tabular}{|c|c|c|c|c|c|c|}
\hline \multicolumn{2}{|c|}{ Değişken } & İfade & Faktör Yükü & $\begin{array}{l}\text { Cronbach Alfa } \\
\text { Değeri }\end{array}$ & $\mathrm{CR}$ & AVE \\
\hline \multirow{15}{*}{$\begin{array}{c}\text { Örgütsel } \\
\text { Adalet }\end{array}$} & \multirow{6}{*}{$\begin{array}{l}\text { İşlem } \\
\text { Adaleti }\end{array}$} & İA1 & 0,941 & \multirow{6}{*}{0,970} & \multirow{6}{*}{0,976} & \multirow{6}{*}{0,872} \\
\hline & & İA2 & 0,949 & & & \\
\hline & & İA3 & 0,950 & & & \\
\hline & & İA4 & 0,944 & & & \\
\hline & & İA5 & 0,929 & & & \\
\hline & & İA6 & 0,888 & & & \\
\hline & \multirow{9}{*}{$\begin{array}{c}\text { Etkileşim } \\
\text { Adaleti }\end{array}$} & EA1 & 0,853 & \multirow{9}{*}{0,970} & \multirow{9}{*}{0,974} & \multirow{9}{*}{0,807} \\
\hline & & EA2 & 0,894 & & & \\
\hline & & EA3 & 0,894 & & & \\
\hline & & EA4 & 0,921 & & & \\
\hline & & EA5 & 0,925 & & & \\
\hline & & EA6 & 0,915 & & & \\
\hline & & EA7 & 0,927 & & & \\
\hline & & EA8 & 0,920 & & & \\
\hline & & EA9 & 0,831 & & & \\
\hline & & CG5 & 0,857 & 0,882 & 0,926 & 0,807 \\
\hline
\end{tabular}


M. Öztürk - K. Vatansever 12/4 (2020) 3613-3632

\begin{tabular}{|c|c|c|c|c|c|c|}
\hline \multirow[t]{12}{*}{$\begin{array}{l}\text { Örgütsel } \\
\text { Güven }\end{array}$} & $\begin{array}{c}\text { Çalışma } \\
\text { Arkadaşına } \\
\text { Güven }\end{array}$ & CG6 & 0,923 & & & \\
\hline & \multirow{6}{*}{$\begin{array}{l}\text { Yöneticiye } \\
\text { Güven }\end{array}$} & YG1 & 0,919 & \multirow{6}{*}{0,978} & \multirow{6}{*}{0,978} & \multirow{6}{*}{0,882} \\
\hline & & $\mathrm{YG} 2$ & 0,925 & & & \\
\hline & & YG3 & 0,946 & & & \\
\hline & & YG4 & 0,948 & & & \\
\hline & & YG5 & 0,952 & & & \\
\hline & & YG6 & 0,945 & & & \\
\hline & \multirow{5}{*}{$\begin{array}{l}\text { Örgüte } \\
\text { Güven }\end{array}$} & ÖG1 & 0,846 & \multirow{5}{*}{0,958} & \multirow{5}{*}{0,968} & \multirow{5}{*}{0,858} \\
\hline & & ÖG2 & 0,942 & & & \\
\hline & & ÖG3 & 0,952 & & & \\
\hline & & ÖG4 & 0,951 & & & \\
\hline & & ÖG5 & 0,951 & & & \\
\hline \multirow{9}{*}{\multicolumn{2}{|c|}{ İşe Adanmışlık }} & İSE1 & 0,811 & \multirow{9}{*}{0,960} & \multirow{9}{*}{0,965} & \multirow{9}{*}{0,753} \\
\hline & & İSE2 & 0,865 & & & \\
\hline & & İSE3 & 0,894 & & & \\
\hline & & İSE4 & 0,901 & & & \\
\hline & & İSE5 & 0,893 & & & \\
\hline & & İSE6 & 0,865 & & & \\
\hline & & İSE7 & 0,849 & & & \\
\hline & & İSE8 & 0,860 & & & \\
\hline & & İSE9 & 0,867 & & & \\
\hline
\end{tabular}

Yapılan faktör analizi sonucunda, her bir faktör değerinin 0,70 veya üzerinde olması gerekmektedir (Henseler vd, 2009:300). Bu sebeple araştırma modelinde faktör yükleri 0,70'in altında kalan CG1, CG2, CG3, CG4 ifadeleri kriteri sağlamadığı için modelden çıkarılmış ve model revize edilerek analizlere devam edilmiştir. Ölçeklerin iç tutarlılık güvenilirliğini sağlaması için Cronbach Alfa değerinin 0,70 ve üzerinde olması gerekmektedir (Urbach ve Ahlemann, 2010). Tablo 1 incelendiğine ölçeklere ait Cronbach Alfa değerlerinin tamamının 0,70'in üzerinde olduğu görülmektedir. Bu anlamda ölçeklerin yüksek bir iç tutarlılığa sahip olduğu ifade edilebilir. Diğer taraftan PLS-SEM modelinde Cronbach Alfa değerine alternatif olarak Composite Reliability (CR) değeri kabul edilmektedir. Bu değerin de 0,70 ve üzeri olması beklenmektedir (Hair vd., 2010). Ölçüm modelinin birleşik geçerliliğini sağlayıp sağlamadığını görmek için AVE değerine bakılması gerekir. Fornelll ve Lacker (1981) yapının birleşik geçerlilik özelliğini taşıması için AVE değerinin 0,5'den büyük olması gerektiğini belirtmişlerdir (Falk ve Miller, 1992). Tablo 1 de yer alan AVE değerleri incelendiğinde tüm değerlerin $0,5^{\prime}$ den büyük olduğu görülmektedir. Dolayısılla araştırmada önerilen modelde yer alan yapıların güvenilir olduğu ifade edilebilir.

\subsubsection{Geçerlilik Analizleri}

Güvenilirlik analizinden sonraki adımda modeldeki her bir değişkenin farklı bir kavramı ölçtüğünü ifade eden ayrışma (discrimant) geçerliliği sonuçları incelenmekledir. Ayrışma geçerliliği için; Fornell-Lacker, Çapraz yük değerleri ve Heterotrait-Monotrait olmak üzere 3 farklı kriter bulunmaktadır (Kağnıcıŏlu ve Çolak, 2019). Fornell-Lacker kriterinin sağlanması için her bir yapının AVE değerlerinin kareköklerinin diğer yapılarla olan korelasyon değerlerinden daha yüksek olması gerekmektedir (Henseler vd., 2016). Aşağıdaki tabloda ayrışma geçerliliği sonuçları verilmiştir.

Tablo 2: Ayrışma Geçerliliği Sonuçları (Fornell-Lacker Kriteri)

\begin{tabular}{|c|c|c|c|c|c|c|}
\hline & $\begin{array}{c}\text { Çalışma } \\
\text { Arkadaşına } \\
\text { Güven }\end{array}$ & $\begin{array}{c}\text { Etkileşim } \\
\text { Adaleti }\end{array}$ & $\begin{array}{c}\text { İşe } \\
\text { Adanmışlık }\end{array}$ & $\begin{array}{c}\text { İşlem } \\
\text { Adaleti }\end{array}$ & $\begin{array}{c}\text { Örgüte } \\
\text { Güven }\end{array}$ & $\begin{array}{c}\text { Yöneticiye } \\
\text { Güven }\end{array}$ \\
\hline ÇalışmaArkadaşına Güven & $\mathbf{0 , 8 9 8}$ & & & & & \\
\hline EtkileşimAdaleti & 0,536 & $\mathbf{0 , 8 9 8}$ & & & & \\
\hline İşeAdanmışlık & 0,319 & 0,659 & $\mathbf{0 , 8 6 8}$ & & & \\
\hline İşlem Adaleti & 0,528 & 0,891 & 0,637 & $\mathbf{0 , 9 3 4}$ & & \\
\hline ÖrgüteGüven & 0,576 & 0,817 & 0,745 & 0,769 & $\mathbf{0 , 9 2 6}$ & \\
\hline Yöneticiye Güven & 0,514 & 0,892 & 0,728 & 0,834 & 0,839 & $\mathbf{0 , 9 3 9}$ \\
\hline
\end{tabular}


Tablo 2 de koyu renk ile işaretlenmiş değerler AVE değerinin kareköküdür. Bu değerler incelendiğinde her bir yapının AVE değerinin diğer yapılarla korelasyonundan daha yüksek olduğu görülmektedir. Örnek olarak açıklamak gerekirse; Çalışma Arkadaşına Güven değişkenine ait AVE değerinin karekökü olan 0,898, Çalışma Arkadaşlarına Güven değişkenin diğer değişkenlerle olan korelasyon değerinden daha yüksek olmaktadır. $\mathrm{Bu}$ durum diğer değişkenler içinde sağlandığından Fornell-Lacker kriteri sağlanmış olmaktadır. Ayrışma geçerliliğinin sağlanması için bakılması gereken bir başka değer Heterotrait-Monotrait (HTMT) değeridir. HTMT değerinin 1'den küçük olması gerekmektedir (Gaskin vd., 2018: 68). Tablo 3 incelendiğinde tüm değerlerin 1'den küçük olduğu görülmektedir. Dolayısıyla Tablo 2 ve Tablo 3'deki bulgulara bakılarak ayrışma geçerliliğinde sağlandığı söylenebilir.

Tablo 3: Ayrışma Geçerliliği Sonuçları (Heterotrait-Monotrait Kriteri)

\begin{tabular}{|l|c|c|c|c|c|c|}
\hline & $\begin{array}{c}\text { Çalışma } \\
\text { Arkadaşına } \\
\text { Güven }\end{array}$ & $\begin{array}{c}\text { Etkileşim } \\
\text { Adaleti }\end{array}$ & $\begin{array}{c}\text { İşe } \\
\text { Adanmışlık }\end{array}$ & İşlem Adaleti & $\begin{array}{c}\text { Örgüte } \\
\text { Güven }\end{array}$ & $\begin{array}{c}\text { Yöneticiye } \\
\text { Güven }\end{array}$ \\
\hline $\begin{array}{l}\text { Çalışma Arkadaşına } \\
\text { Güven }\end{array}$ & & & & & & \\
\hline Etkileşim Adaleti & 0,567 & & & & & \\
\hline İşe Adanmışlı & 0,300 & 0,659 & & & & \\
\hline İslem Adaleti & 0,558 & 0,919 & 0,638 & & & \\
\hline Örgüte Güven & 0,613 & 0,847 & 0,748 & 0,798 & & \\
\hline Yöneticiye Güven & 0,540 & 0,917 & 0,734 & 0,857 & 0,858 & \\
\hline
\end{tabular}

Yapılan güvenilirlik ve geçerlilik analizlerinden sonra modelin uyum iyiliği indeksine bakılmıştır. Uyum iyiliği değerini ifade eden Gof'da $\mathrm{R}^{2}$ ve $\mathrm{Q}^{2}$ değerleri yer alır. Tenenhausa ve arkadaşları (2005)'nın geliştirdiği yöntemde Gof değeri AVE değerlerinin ortalaması ve $R^{2}$ değerlerinin ortalamasının çarpımı sonucu elde edilen değerin karekökünün alınmasıyla elde edilmektedir. Hesaplama sonucu elde edilen değer; $0,1^{\prime}$ den küçük ise kötü, 0,1 ile 0,25 arasında ise düşük, 0,25 ve 0,36 arasında ise orta ve 0,36 'dan büyük ise yüksek olarak değerlendirilmektedir (Wetzels vd., 2009). Bu hesaplama aşağıdaki şekilde formülüze edilebilir:

Tablo 4: Uyum İyiliği İndeksi (GoF)

\begin{tabular}{|l|c|c|c|}
\hline & AVE & $\mathbf{R}^{\mathbf{2}}$ & $\mathbf{Q}^{\mathbf{2}}$ \\
\hline Etkileşim Adaleti & 0,807 & & \\
\hline İşlem Adaleti & 0,872 & & 0,70 \\
\hline Yöneticiye Güven & 0,882 & 0,803 & 0,22 \\
\hline Çalış̧ma Ark. Güven & 0,807 & 0,300 & 0,57 \\
\hline Örgüte Güven & 0,858 & 0,676 & 0,44 \\
\hline İsse Adanmışlık & 0,753 & 0,620 & \\
\hline Ortalama & 0,968 & 0,599 & \\
\hline
\end{tabular}

Gof $=\sqrt{ } R^{2} . A V E$

Çarpım Sonucu $\left(\mathrm{AVE}^{*} \mathrm{R}^{2}\right)=0,579832$

Gof $=0,761$

Hesaplanan Gof Değeri modelin yüksek uyum iyiliği özelliği taşıdığını ortaya koymaktadır. Bir yapının ilişkili değerler tarafından ne kadar açıklandığını görmek için $\mathrm{R}^{2}$ değerine bakılmaktadır. Diğer bir ifadeyle $\mathrm{R}^{2}$ değeri bağımsız değişkenlerin ilişkide olduğu bağımlı değişkenleri ne kadar açıkladığını göstermektedir. $R^{2}$ değeri 0,19- zayıf, 0,33-orta ve 0,67-yüksek seviye olarak değerlendirilmektedir (Chin, 1998:323). Buna göre Tablo 4 de verilen $\mathrm{R}^{2}$ değerine bakıldığında; Etkileşim Adaleti ve İşlem Adaleti yapılarının Yöneticiye Güveni \%80 olarak yüksek bir seviyede, Çalışma Arkadaşına Güveni \%30 olarak zayıf bir seviyede, Örgüte Güveni \%67 olarak yüksek bir seviyede açıkladığı görülmektedir. İşe Adanmışlık boyutunun ise diğer tüm yapılar tarafından \%62'lik bir oranla orta seviyede açıklandığı tespit edilmiştir. Yapısal modelin analizinde dikkate alınması gereken bir diğer değer $\mathrm{Q}^{2}$ değeridir. SmartPLS 3.2.9 programında Blindfolding prosedürü uygulanarak elde edilen $\mathrm{Q}^{2}$ değeri modelin tahmin gücünü belirlemek için kullanılır. Bu değerin $0^{\prime}$ dan büyük olması beklenir ve değer 0 dan ne kadar büyükse tahmin gücü o kadar yüksek olarak değerlendirilir (Hair vd., 2017: 217-224). Buna göre Tablo 4'deki $\mathrm{Q}^{2}$ değerlerine bakıldığında modelin tahmin gücünün yüksek seviyede olduğu söylenebilir. 


\section{Bulgular}

\section{Katılımcıların Demografik Özellikleri}

Katılımcıların; \%55,3'ünü kadınlar, \%44,7'sini ise erkekler oluşturmaktadır. Katılımcıların \% 7,3'ünün 18-25 yaş aralığında, \%44,8'inin 26-35 yaş aralığında, \%23,7'sinin 36-40 yaş aralığında ve \%24,2'sinin de 41 yaş ve üzerinde olduğu görülmüştür. Katılımcıların, ağırlıklı çoğunluğu evli çalışanlardan oluşmaktadır. Bekarların oranı ise \%20,1 olarak kalmıştır. Katılımcıların kurumda çalışma sürelerine bakıldığında \%27,9 oranı ile 8-11 yıl arası çalışanların çoğunluğu oluşturduğu görülmektedir. Katılımcıların eğitim durumu incelendiğinde yarısına yakınının lise mezunu olduğu sonucuna ulaşılmıştır. Lisans eğitimi alanların oranı \%23,3 iken lisansüstü eğitime sahip personelin oranı ise \%2,7 olarak belirlenmiştir. Katılımcıların ağırlıklı çoğunluğunu \%71,7 ile taşeron statüsünde çalışanlar oluşturmaktadır. Devlet memuru statüsünde çalışanların oranı \%13,7, Sözleşmeli çalışanların oranı \%8,2 ve Daimî İşçi statüsünde çalışanların oranı ise \%6,4 olduğu belirlenmiştir.

\section{Araştırma Modelinin Test Edilmesi}

Araştırma modelinin tüm güvenilirlik ve geçerlilik analizlerinden elde edilen sonuçların istenilen düzeyde olmasından sonra araştırmanın hipotezlerini sınamak için yapısal model analizi gerçekleştirilmiştir. Bu analizde; araştırmanın bağımsız değişkenlerinin bağımlı değişkenler üzerindeki etkisinin belirlenmesi amaçlanmıştır.

Tablo 5: Ölçüm Modeli Sonuçları

\begin{tabular}{|c|c|c|c|c|c|c|}
\hline & $\begin{array}{c}\text { Standardize } \boldsymbol{\beta} \\
\text { Katsay1si }\end{array}$ & $\begin{array}{c}\text { Sample Mean } \\
\text { (M) }\end{array}$ & $\begin{array}{c}\text { Standard Deviation } \\
\text { (STDEV) }\end{array}$ & $\begin{array}{c}\text { T Statistics } \\
(\mid \mathbf{O} / \text { STDEV I) }\end{array}$ & $\begin{array}{c}\mathbf{P} \\
\text { Values }\end{array}$ & Karar \\
\hline $\mathbf{H}_{\mathbf{1}}$ & $-0,163$ & $-0,162$ & 0,136 & 1,197 & 0,231 & RED \\
\hline $\mathbf{H}_{\mathbf{2}}$ & 0,642 & 0,641 & 0,083 & 7,696 & $0,000^{* * *}$ & KABUL \\
\hline $\mathbf{H}_{\mathbf{3}}$ & 0,322 & 0,322 & 0,121 & 2,659 & $0,008^{* * *}$ & KABUL \\
\hline $\mathbf{H}_{\mathbf{4}}$ & 0,723 & 0,724 & 0,070 & 10,350 & $0,000^{* * *}$ & KABUL \\
\hline $\mathbf{H}_{\mathbf{5}}$ & 0,096 & 0,095 & 0,099 & 0,971 & 0,332 & RED \\
\hline $\mathbf{H}_{\mathbf{6}}$ & 0,197 & 0,197 & 0,084 & 2,339 & $0,019^{* *}$ & KABUL \\
\hline $\mathbf{H}_{\mathbf{7}}$ & 0,242 & 0,244 & 0,126 & 1,924 & 0,054 & RED \\
\hline $\mathbf{H}_{\mathbf{8}}$ & 0,189 & 0,189 & 0,078 & 2,431 & $0,015^{* *}$ & KABUL \\
\hline $\mathbf{H}_{9}$ & 0,551 & 0,555 & 0,095 & 5,814 & $0,000^{* * *}$ & KABUL \\
\hline $\mathbf{H}_{\mathbf{1}}$ & $-0,188$ & $-0,186$ & 0,060 & 3,110 & $0,002^{* * *}$ & RED \\
\hline $\mathbf{H}_{\mathbf{1 1}}$ & 0,428 & 0,424 & 0,116 & 3,686 & $0,000^{* * *}$ & KABUL \\
\hline
\end{tabular}

${ }^{* * *} \mathrm{p}<0,01$ (\%1 hata pay1 \%99 önemlilik) ${ }^{* *} \mathrm{p}<0,05$ (\%5 hata pay1 \%95 önemlilik) ${ }^{*} \mathrm{p}<0,1$ (\%10 hata pay1 \%90 önemlilik)

Smart PLS programında yol katsayılarının anlamlılıklarını ölçmek amacıyla yeniden örnekleme işlemi (bootsrapping) yapılarak örneklemden 5000 alt örneklem alınarak p değeri hesaplanmıştır. Etkileşim adaleti boyutunun işe adanmışlık üzerindeki etkisine ilişkin $\mathrm{H}_{1}$ hipotezi incelendiğinde, $\mathrm{p}=0,231$ ( $\left.p>0,1\right)$ olduğu için hipotez anlamlı bulunmamıştır. Dolayısıyla $\mathrm{H}_{1}$ hipotezi reddedilmiştir. Etkileşim adaleti boyutunun örgüte güven üzerindeki etkisine ilişkin $\mathrm{H}_{2}$ hipotezi incelendiğinde, $\mathrm{p}=0,000(\mathrm{p}<0,01)$ hipotez anlamlı bulunmuş ve $\mathrm{H}_{2}$ hipotezi desteklenmiştir. Etki oranını gösteren standardize $\beta$ katsayısı incelendiğinde ise işlem adaleti boyutunun $\beta=0,642$ 'lik bir etkiye sahip olduğu görülmektedir. Etkileşim adaleti boyutunun çalışma arkadaşına güven boyutu üzerindeki etkisine ilişkin $\mathrm{H}_{3}$ hipotezi incelendiğinde, $\mathrm{p}=0,008(\mathrm{p}<0,01)$ hipotez anlamlı bulunmuş ve $\mathrm{H}_{3}$ hipotezi desteklenmiştir. Etkileşim adaleti boyutunun çalışma arkadaşına güven boyutu üzerindeki etki oranını gösteren standardize $\beta$ katsayısı incelendiğinde ise $\beta=0,322^{\prime}$ lik bir etkide bulunduğu görülmektedir. Etkileşim adaleti boyutunun yöneticiye güven boyutu üzerindeki etkisine ilişkin $\mathrm{H}_{4}$ hipotezi incelendiğinde, $\mathrm{p}=0,000(\mathrm{p}<0,01)$ hipotez anlamlı bulunmuş ve $\mathrm{H}_{4}$ hipotezi desteklenmiştir. Etki oranını gösteren standardize $\beta$ katsayısı incelendiğinde ise etkileşim adaleti boyutunun çalışma arkadaşına güven boyutu üzerinde $\beta=0,723^{\prime}$ lük bir etkiye sahip olduğu görülmektedir. İşlem adaleti boyutunun işe adanmışlık boyutu üzerindeki etkisine ilişkin $\mathrm{H}_{5}$ hipotezi incelendiğinde, $\mathrm{p}=0,322(\mathrm{p}>0,1)$ olduğu için hipotez anlamlı bulunmamış ve reddedilmiştir. İşlem adaleti boyutunun örgüte güven boyutu üzerindeki etkisine ilişkin $\mathrm{H}_{6}$ hipotezi incelendiğinde, $\mathrm{p}=0,19(\mathrm{p}<0,05)$ hipotez anlamlı bulunmuş ve desteklenmiştir. Etki oranını gösteren standardize $\beta$ katsayısı incelendiğinde ise $\beta=0,197^{\prime}$ lik bir etkide bulunduğu görülmektedir. İşlem 


\section{M. Öztürk - K. Vatansever 12/4 (2020) 3613-3632}

adaleti boyutunun çalışma arkadaşlarına güven boyutu üzerindeki etkisine ilişkin $\mathrm{H} 7$ hipotezi incelendiğinde, $\mathrm{p}=0,54$ ( $\mathrm{p}>0,1)$ olduğu için hipotez anlamlı bulunmamış ve desteklenmemiştir. İşlem adaleti boyutunun yöneticiye güven boyutu üzerindeki etkisine ilişkin $\mathrm{H}_{8}$ hipotezi incelendiğinde, $\mathrm{p}=0,15 \quad(\mathrm{p}<0,05)$ hipotez anlamlı bulunmuş ve desteklenmiştir. Standardize edilmiş $\beta$ katsayısı incelendiğinde ise $\beta=0,189^{\prime}$ luk bir etkiye sahip olduğu görülmektedir. Örgüte güven boyutunun işe adanmışlık boyutu üzerindeki etkisine ilişkin $\mathrm{H}_{9}$ hipotezi incelendiğinde, $\mathrm{p}=0,000(\mathrm{p}<0,01)$ hipotez anlamlı bulunmuş ve desteklenmiştir. Etki oranını gösteren $\beta$ katsayısı incelendiğinde ise örgüte güven boyutunun işe adanmışlık boyutu üzerinde $\beta=0,551$ 'lik bir etkisinin olduğu görülmektedir. Çalışma arkadaşına güven boyutunun işe adanmışlık boyutu üzerindeki etkisine ilişkin $\mathrm{H}_{10}$ hipotezi $\mathrm{p}=0,002(\mathrm{p}<0,01)$ anlamlı bulunmuş ancak negatif bir etkiye sahip olduğu için $(\beta=$ $-0,188$ ) hipotez reddedilmiştir. Son olarak yöneticiye güven boyutunun işe adanmışlık boyutu üzerindeki etkisine ilişkin $\mathrm{H}_{11}$ hipotezi incelendiğinde, $\mathrm{p}=0,000(\mathrm{p}<0,001)$ olduğu için anlamlı bulunmuş ve hipotez desteklenmiştir. Standardize edilmiş $\beta$ katsayısı incelendiğinde ise yöneticiye güven boyutunun işe adanmışlık boyutu üzerinde $\beta=0,428^{\prime}$ lik bir etkiye sahip olduğu görülmektedir.

\section{Sonuç ve Tartışma}

Bu çalışmada Alanya Belediyesi çalışanlarının örgütsel adalet ve örgütsel güven algıları ile işe adanmışlıkları arasındaki ilişkinin belirlenmesi amaçlanmıştır. Araştırma, kolayda örnekleme yönetmiyle seçilen 219 çalışan üzerinde gerçekleştirilmiştir. Bilimsel çalışmaların ilk koşullarından birisinin verilerin güvenilir ve geçerli olması sebebiyle elde edilen verilere güvenilirlik ve geçerlilik analizleri yapılmıştır. Yapılan güvenilirlik analizleri sonucunda ölçeklerin güvenilirlik katsayılarının (Cronbach's Alfa) oldukça yüksek olduğu görülmüştür. Ölçeklerin geçerliliğini ölçmek için ayrışma geçerliliği (discriminant) analizi yapılmıştır. Burada Fornell-Lacker ve Heterotrait-Monotrait değerlerinin istenen düzeyde olduğu görüldükten sonra araştırma ölçeklerinin güvenilir ve geçerli olduğu sonucuna ulaşılmıştır. Daha sonra ise araştırmaya katılan katılımcıların demografik bulgularına yer verilmiş, araştırma modeli test edilmiştir.

Yapılan hipotez testleri sonucunda etkileşim adaleti boyutunun, örgütsel güvenin tüm boyutları üzerinde anlamlı bir etkiye sahip olduğu sonucuna ulaşılmıştır. Bununla birlikte etkileşim adaletinin, en büyük etkisinin yöneticiye güven boyutu üzerinde olduğu görülmektedir. Bu sonucun Sakallı (2015),Seifert ve arkadaşları (2013), Abr Rowa ve arkadaşları (2013), Polat (2007), Wong ve arkadaşları (2006)'nın yaptıkları çalışmalar sonucuyla paralellik gösterdiği görülmektedir. Etkileşim adaleti, daha önce ifade edildiği üzere özellikle örgüt yöneticilerinin çalışanlarla olan iletişim şekline odaklanmaktadır. Yöneticiler, örgütteki iş ve işlemlerle ilgili süreçlerden çalışanları düzenli bir şekilde bilgilendiriyor, çalışanlarla düzgün, açık ve nezaketli bir şekilde iletişim kuruyorsa çalışanların etkileşim adaleti algısı yüksek olmaktadır. Dolayısıyla araştırmanın bu sonucuna göre, yöneticilerin çalışanlarla kurdukları iletişimin şekli, düzeyi, sürekliliğinin çalışan-yönetici güveninin sağlanmasında direkt olarak etkili olduğu çıkarımı yapılabilmektedir. Araştırma sonuçlarına bakıldığında, işlem adaleti boyutunun işe adanmışlık ve yöneticiye güven üzerinde düşük düzeyde de olsa anlamlı bir etkisinin olduğu görülmektedir. Araştırmanın bu sonucunun Park ve arkadaşları (2016), Ghosh ve arkadaşları (2014), Akyel (2014), Inoue ve arkadaşları (2010), Li ve arkadaşları (2010), Alexander ve Ruderman (1987)'nın yapmış oldukları çalışma sonuçlarıyla benzeştiği görülmektedir. Buna göre örgütsel kaynakların dağıtımı ve örgütsel kararların alınması ile ilgili sürece çalışanların katılımının sağlanması, bu kararların hangi kriterlere göre alındığı ile ilgili çalışanların bilgilendirilmesinin, çalışanların yöneticilerine güven duymaları ve kendilerini işlerine adamaları üzerinde etkili olduğu yorumu yapilabilmektedir.

Örgütsel güven boyutlarının, işe adanmışlık üzerindeki etkisine bakıldığında ise örgüte güven ve yöneticiye güven boyutlarının anlamlı bir etkiye sahip olduğu sonucuna ulaşılmıştır. Özellikle örgüte güven boyutu, yöneticiye güven boyutuna göre işe adanmışlık üzerinde daha büyük bir etkiye sahiptir. Bu sonuçlar literatürdeki araştırmalarla da benzerlik göstermektedir (Gülbahar 2017; Ugwu vd., 2014; Lin, 2010). Kurumlar için kendini işine adamış, örgütün kültürü ile uyum sağlamış çalışanları istihdam etmek ve bunların örgütte sürekliliğini sağlamak, örgütsel verimlilik açısından büyük bir öneme sahiptir. Bu çalışma sonucu da göstermiştir ki çalışanların kendilerini işe adamalarında örgütlerine duydukları güvenin büyük bir önemi vardır. Dolayısıyla örgütlerin kurumsal olarak, bireylerin arkasında olduğunu hissettirmesi, onlara değer verdiğini göstermesi ve çalışanlarına güven vermesi, çalışanların kendilerini işlerine adamalarında önemli bir etkiye sahip olmaktadır. 


\section{M. Öztürk - K. Vatansever 12/4 (2020) 3613-3632}

Halkla birebir temas kuran ve günlük yaşantısına direkt olarak etki eden alanlarda halka hizmet götürmekle sorumlu olan belediyelerin, seçildikleri dönemlerdeki performansları sonraki seçim sonuçları açısından büyük bir öneme sahiptir. Bu dönemin, verimli ve etkili bir şekilde geçirilip vatandaşın memnun edilmesi ise iyi bir ekip çalışmasıyla mümkün olmaktadır. Bu araştırma sonucuyla da görülmektedir ki çalışanların kendilerini işlerine adamalarında örgütsel güven, örgütsel güvenin oluşmasında ise örgütsel adalet önemli bir etkiye sahip olmaktadır. Dolasıyla örgütsel adalet algısının olmadığı örgütlerde güven duygusu oluşmayacak, güven duygusunun oluşmadığı kurum çalışanlarında ise işe adanma düzeylerinde düşüş olacaktır. Kurumlar, çalışanlarından maksimum seviyede verimlilik elde edebilmek için örgütlerde iş ve işlemlerin hangi kriterlere göre yapıldığını çalışanları ile paylaşmalı, örgüt yöneticileri ise bu süreçlerle ilgili tüm çalışanların aynı ölçüde ve nezaketle bilgilendirilmesini sağlamalıdır. Bu şekilde kurumda oluşacak örgütsel güven de çalışanların kendilerini işlerine adamlarına katkı sağlayacaktır.

\section{KAYNAKÇA}

Abr Rowa, H. A., Ardakani, M. S., Harooni, A. and Pour, H.M. (2013). The Relationship Between Organizational Trust and Organizational Justice Components and Their Role in Job Involvement in Education., International Journal of Management Academy, 1(1) : 25-41.

Adams, J. S. (1965). Inequity in social exchange, In Advances in experimental social psychology, Academic Press, 2 : 267-299.

Adams, S.H. (2004). The relationships among adult attachment, general self- disclosure, and perceived organizational trust, Yayımlanmamış Doktora Tezi, Virginia Polytechnic Institute and State University, Virginia.

Aktuğ, M. (2016). Örgütsel Adalet Ve Örgütsel Güvenin Çalışan Performansı Üzerine Etkisi, Yayımlanmamış Yüksek Lisans Tezi, Gelişim Üniversitesi, Sosyal Bilimler Enstitüsü, İstanbul.

Akyel, Y. (2014). Örgütsel Adalet ve Örgütsel Güven İlişkisi, Yayımlanmamış Doktora Tezi, Gazi Üniversitesi, Sağlık Bilimleri Enstitüsü, Ankara.

Alanya Belediyesi. (2019). Alanya Belediyesi Faaliyet Raporu 2019, https://www.alanya.bel.tr/Documents/Faaliyet/2019/2019.pdf (Erişim Tarihi: 14 Eylül 2020).

Alexander, S. and Ruderman, M. (1987). The role of procedural and distributive justice in organizational behavior, Social justice research, 1(2) : 177-198.

Altıntaş, F. Ç. (2006). Bireysel değerlerin örgütsel adalet ve sonuçları ilişkisinde yönlendirici etkisi: Akademik personel üzerinde bir analiz, İşletme Fakültesi Dergisi, 2(7) : 19-40.

Arabacı, T. (2012). The role of organizational trust on work engagement-with the moderating effect of work pressure, Yayımlanmamış Yüksek Lisans Tezi, Marmara Üniversitesi, Sosyal Bilimler Enstitüsü, İstanbul.

Arslan, Ö. E. and Yavuz, E. (2019). Örgütsel Adalet, Örgütsel Anomi Ve Örgütsel Güven Arasındaki İlişki: Otel İşletmelerinde Bir Araştırma, Electronic Turkish Studies, 14(2) : 113-134.

Arslan, Y. (2009). Kurumsallaşma ve örgütsel güven ilişkisi, Yayımlanmamış Yüksek Lisans Tezi, Gebze Yüksek Teknoloji Enstitüsü, Sosyal Bilimler Enstitüsü, Kocaeli.

Aryee, S., Budhwar, P. S. and Chen, Z. X. (2002). Trust as a mediator of the relationship between organizational justice and work outcomes: Test of a social exchange model. Journal of Organizational Behavior: The International Journal of Industrial, Occupational and Organizational Psychology and Behavior, 23(3), 267-285.

Aslan, Ş. and Özata, M. (2009). Lider-üye etkileşiminin (LMX) yöneticiye duyulan güven düzeyine etkisi, SÜ İBF Sosyal ve Ekonomik Araştırmalar Dergisi, 17: 95-116.

Asunakutlu, T. (2002). Örgütsel Güvenin Oluşturulmasına İlişkin Unsurlar Ve Bir Değerlendirme, Muğgla Üniversitesi Sosyal Bilimler Enstitüsü Dergisi, 9:1-13.

Ay, G. and Koç, H. (2014). Örgütsel Adalet Algısı ile Örgütsel Bağlılık Düzeyi Arasındaki İlişkinin Belirlenmesi: Öğretmenler Üzerine Bir İnceleme, İşletme Araştırmaları Dergisi, 6(2), 67-90.

Babaoğlan, E. and Ertürk, E. (2013). Öğretmenlerin örgütsel adalet algısı ile örgütsel adanmışlıkları arasındaki ilişki, Hacettepe Üniversitesi Ĕ̆itim Fakültesi Dergisi, 28(2), 87-101. 
Bachmann, R. (2002). Trust and power as means of co-ordinating the internal relations of the organization: a conceptual

framework.

https://www.researchgate.net/search/publication?q=Trust $\% 20$ and $\% 20$ Power\%20as\%20Means\%20of \%20Coordinating\%20the\%20Internal\%20Relations\%20of\%20the\%200rganization\%20\%20A\%20Conceptual\%20Framework, (Erişim Tarihi: 28 Ekim 2020).

Bakker, A. B., Albrecht, S. L. and Leiter, M. P. (2011). Key questions regarding work engagement, European Journal of Work and Organizational Psychology, 20(1), 4-28.

Bakker, A. B. and Bal, M. P. (2010). Weekly work engagement and performance: A study among starting teachers, Journal of occupational and organizational psychology, 83(1), 189-206.

Bakker, A. B. and Demerout1, E. (2008). Towards a model of work engagement, Career Development International, 13(3) : 209-223.

Bakker, A. B., Schaufeli, W. B., Leiter, M. P. and Taris, T. W. (2008). Work engagement: An emerging concept in occupational health psychology, Work \& stress, 22(3), 187-200.

Beugre, C. D. and Baron, R. A. (2001). Perceptions of systemic justice: The effects of distributive, procedural, and interactional justice, Journal of Applied Social Psychology, 31(2) : 324-339.

Boylu, Y. and Yıldırım, M. (2018). The relationship of psychological contract breach between organizational trust and organizational cynicism: A study in hotels. İs, Güç, The Journal of Industrial Relations and Human Resources, 20(3), 25-48.

Büte, M. (2011). Etik iklim, örgütsel güven ve bireysel performans arasindaki ilişki, Atatürk Üniversitesi İktisadi ve İdari Bilimler Dergisi, 25(1) : 171-192.

Carr, A. (2016). Pozitif Psikoloji Mutluluğun ve İnsanın Güçlü Yönlerinin Bilimi, (Ü.Şendilek, Çev.), İstanbul, Kaknüs Yayıncilık.

Chin, W.W. (1998). The Partial Least Squares Approach to Structural Equation Modeling, Modern Methods for Business Research, 295(2) : 295-336.

Chory, R. M. (2008). Organizational Justice and Managerial Trust as Predictors of Antisocial Employee Responses, Communication Quarterly, 56 (4) :357-375.

Cihangiroğlu, N. and Yılmaz, A. (2010). Çalışanların örgütsel adalet algısının örgütler için önemi, SÜ İ̈BF Sosyal ve Ekonomik Araştırmalar Dergisi, 19: 195-213.

Cohen-Charash, Y. and Spector, P. E. (2001). The role of justice in organizations: A meta-analysis, Organizational behavior and human decision processes, 86(2), 278-321.

Colquitt, J. A. (2001). On the dimensionality of organizational justice: A construct validation of a measure, Journal of applied psychology, 86(3), 386-400.

Colquitt, J. A. (2004). Does the justice of the one interact with the justice of the many? Reactions to procedural justice in teams, Journal of Applied Psychology, 89(4), 633-646.

Colquitt, J. A., Conlon, D. E., Wesson, M. J., Porter, C. O. and Ng, K. Y. (2001). Justice at the millennium: a meta-analytic review of 25 years of organizational justice research, Journal of Applied Psychology, 86(3) : 425-445.

Conlon, D. E., Meyer, C. J. and Nowakowski, J. M. (2005). How does organizational justice affect performance, withdrawal, and counterproductive behavior?, Greenberg, J. and Colquitt, J.A.(Ed.), Handbook of organizational justice, Lawrence Erlbaum Associates Publishers, New Jersey, 301-327.

Cook, J. and Wall, T. (1980). New work attitude measures of trust, organizational commitment and personal need non-fulfilment, Journal of occupational psychology, 53(1), 39-52.

Cropanzano, R., Bowen, D. E. and Gilliland, S. W. (2007). The management of organizational justice, Academy of management perspectives, 21(4), 34-48. 
M. Öztürk - K. Vatansever 12/4 (2020) 3613-3632

Cropanzano, R., Rupp, D. E., Mohler, C. J. and Schminke, M. (2001). Three roads to organizational justice, Ferris, G. R. (Ed.), Research in Personnel and Human Resources Management, Emerald Group Publishing Limited, Bingley, 1-113.

Culbert, S. A. and Mcdonough, J. J. (1986). The politics of trust and organization empowerment, Public Administration Quarterly, 2(10): 171-188.

Çalışkan, S. (2014). Pozitif örgütsel davranış değişkenleri ile yeni araştırma modelleri geliştirme arayışları: Pozitif örgütsel davranış değişkenlerinin işe adanmışlık, tükenmişlik ve sinizm üzerine etkileri ve bu etkileşimde örgütsel adalet algısının aracılık rolü üzerine bir araştırma, Dokuz Eylül Üniversitesi Sosyal Bilimler Enstitüsü Dergisi, 16(3), 363-382.

Demirhan, M. ve Karaman, A. (2015). Akademisyenlerin adalet ve etik algılarının örgütsel adanmışlıklarına etkisi, Uşak Üniversitesi Sosyal Bilimler Dergisi, 8(4), 245-266.

Dietz, G. and Den Hartog, D. N. (2006). Measuring trust inside organisations, Personnel review, 35(5), 557-588.

Dirks, T. and Ferrin, D. L. (2001). The role of trust in organizational settings, Organization science, 12(4), 450467.

Doney, P. M. and Cannon, J. P. (1997). An examination of the nature of trust in buyer-seller relationships, Journal of marketing, 61(2), 35-51.

Engelbrecht, A. S., Heine, G. and Mahambe, B. (2014). The influence of ethical leadership on trust and work engagement: An exploratory study, SA Journal of Industrial Psychology, 40(1) : 1-9.

Erdirençelebi, M. and Karataş, C. G. (2019). Örgütsel Adaletin İşe Adanmışlık İle İşten Ayrılma Niyeti Üzerine Etkisi, Business \& Management Studies: An International Journal, 7(4) : 1825-1849.

Eroğlu, Ş. G. (2014). Çalışanların Örgütsel Adalet Algısının Örgütsel Güven Üzerindeki Etkileri, Pamukkale İşletme ve Bilişim Yönetimi Dergisi, 1 (1) : 53-66.

Ertürk, A. (2003). Örgütsel iletişim ve adalet algılarının örgütsel kimlik algısı üzerindeki etkileri, Yönetim Araştırmaları Dergisi, 3(2), 147-170.

Farooq, M. and Farooq, O. (2014). Organizational justice, employee turnover, and trust in the workplace: A study in South Asian telecommunication companies, Global Business and Organizational Excellence, 33(3) : 56-62.

Ferres, N., Connell, J. and Travaglion, A. (2004). Co-worker trust as a social catalyst for constructive employee attitudes, Journal of Managerial Psychology, 19(6), 608-622.

Fox, S., Spector, P. E. and Miles, D. (2001). Counterproductive work behavior (CWB) in response to job stressors and organizational justice: Some mediator and moderator tests for autonomy and emotions, Journal of vocational behavior, 59(3), 291-309.

Gaskin, J., Godfrey, S. and Vance, A. (2018). Successful System Use: It's Not Just Who You Are, But What You Do, AIS Transactions on Human-Computer Interaction, 10(2) : 57-81.

Gerome, S. C. (2008). An examination of relationships between transformational leadership behavior and interactive justice perceptions among membership of a local chapter of human resource professionals, Yayımlanmamış Doktora Tezi, Capella University, Minnesota.

Ghosh, P., Rai, A. and Sinha, A. (2014). Organizational justice and employee engagement, Personnel Review, $4(43): 628-652$.

Gilbert, J. A. and Tang, T. L. P. (1998). An examination of organizational trust antecedents, Public Personnel Management, 27(3) : 321-338.

Gonzalez-Roma, V., Schaufeli, W. B., Bakker, A. B. and Lloret, S. (2006). Burnout and work engagement: Independent factors or opposite poles?, Journal of Vocational Behavior, 68(1): 165-174. 
Goblit, T. (2011). Multifoci Organizational Justice, Organizational Citizenship Behavior, and Counterproductive Work Behavior: The Mediating Effects of Emotions. Yayımlanmamış Doktora Tezi, University of California, Florida.

Greenberg, J. (1990). Organizational justice: Yesterday, today, and tomorrow, Journal of Management, 16(2): 399432.

Gülbahar, B. (2017). The relationship between work engagement and organizational trust: A study of elementary school teachers in Turkey, Journal of Education and Training Studies, 5(2):149-159.

Gürbüz, S. and Şahin, F. (2018). Sosyal Bilimlerde Araştırma Yöntemleri Felsefe, Yöntem ve Analiz (5), Ankara, Seçkin Yayıncılık.

Gürpınar, G. (2006). An Empirical study of relationships among organizational justice, organizational commitment, leader-member exchange,and turnover intention. Yayımlanmamış Yüksek Lisans Tezi, Yeditepe Üniversitesi, Sosyal Bilimler Enstitüsü, İstanbul.

Hair, J.F., Hult, J.G, Ringle, C. and Sarstedt, M. (2017). A Premier on Partial Least Squares Structural Equation Modeling (PLS-SEM) (2), California, SAGE Publication.

Hallberg, U. E. and Schaufeli, W. B. (2006). Same same but different? Can work engagement be discriminated from job involvement and organizational commitment?, European Psychologist, 11(2): 119-127.

Henseler, J., Hubona, G. and Ray, P.A. (2016). Using PLS path modeling in new technology research: updated guidelines, Industrial Management \& Data Systems, 116(1) : 2-20.

Henseler, J., Ringle, C.M. and Sinkovics, R.R. (2009). The Use of Partial Least Squares Path Modeling in International Marketing, Sinkovicks, R.R and Ghauri, P. (Ed.), New Challenges to International Marketing, Emerald Group Publishing Limited,Bingley, 277-319.

Hubbell, A. P. and Chory-Assad, R. M. (2005). Motivating factors: Perceptions of justice and their relationship with managerial and organizational trust, Communication Studies, 56(1) : 47-70.

Inoue, A., Kawakami, N., Ishizaki, M., Shimazu, A., Tsuchiya, M., Tabata, M. and Kurod, M. (2010). Organizational justice, psychological distress, and work engagement in Japanese workers, International Archives of Occupational and Environmental Health, 83(1) :29-38.

İçerli, L. (2010). Örgütsel Adalet: Kuramsal Bir Yaklaşım, Girişimcilik ve Kalkınma Dergisi, 5(1) : 67-93.

İşçan, Ö. F., and Sayın, U. (2010). Örgütsel adalet, iş tatmini ve örgütsel güven arasindaki ilişki, Atatürk Üniversitesi İktisadi ve İdari Bilimler Dergisi, 24(4) : 195-216.

İyigün, N. Ö. (2012). Örgütsel adalet: Kuramsal bir yaklaşım, İstanbul Ticaret Üniversitesi Sosyal Bilimler Dergisi, 21: $49-64$.

Jenaro, C., Flores, N., Orgaz, M. B. and Cruz, M. (2011). Vigour and dedication in nursing professionals: towards a better understanding of work engagement. Journal of Advanced Nursing, 67(4) : 865-875.

Kağnıcıoğlu, C.H., and Çolak, H. (2019). Tüketicinin Nesnelerin İnterneti Teknolojilerini Benimsemesi ve Bir Uygulama, Anadolu Üniversitesi Sosyal Bilimler Dergisi, 19(4) : 241-268.

Kahn, W. A. (1990). Psychological Conditions Of Personal Engagement And Disengagement At Work, Academy of Management Journal, 33(4) : 692-724.

Kaneshiro, P. (2008). Analyzing the organizational justice, trust, and commitment relationship in a public organization, Yayımlanmamış Doktora Tezi, Northcentral University, California.

Keleş, S. (2014). Aile Şirketlerinde Y Jenerasyonunun Öz Yeterlilik Algısı Ve İşe Adanmışlık İlişkisi, Süleyman Demirel Üniversitesi Vizyoner Dergisi, 5(11) : 95-109.

Kılınç, B. (2013). Kendi Kendini Açıklayan Bir Kavram: Adalet, Genç Hukukçular Hukuk Okumaları Birikimler Dergisi, 4 : 29-49.

Koç, H. and Yazıcıoğlu, İ. (2011). Yöneticiye Duyulan Güven ile İş Tatmini Arasındaki İlişki: Kamu ve Özel Sektör Karşılaştırması, Doğuş Üniversitesi Dergisi, 12(1) : 46-57. 


\section{M. Öztürk - K. Vatansever 12/4 (2020) 3613-3632}

Koçak, H. and Koç, H. (2018). Psikolojik Sözleşme İhlalleri ile Örgütsel Güven ve Örgütsel Bağlllık İlişkisi: Kamu ve Özel Sektör Karşılaştırması, İşletme Araştırmaları Dergisi, 10(4) : 1217-1241.

Konovsky, M. A. and Cropanzano, R. (1991). Perceived fairness of employee drug testing as a predictor of employee attitudes and job performance, Journal of Applied Psychology, 76(5) : 698-707.

Konovsky, M. A., and Pugh, S. D. (1994). Citizenship behavior and social exchange, Academy of Management Journal, 37(3) : 656-669.

Köksal, K. (2016). Örgüt Kültürünün Örgütsel Adalet Algısına Etkisinde Etik İlkelere İlişkin Algıların Aracllı Rolü, Yayımlanmamış Doktora Tezi, Celal Bayar Üniversitesi, Sosyal Bilimler Enstitüsü, Manisa.

Küçükeşmen, E. (2015). Örgütsel Adalet Algısı ve Örgütsel Bağllı̆̆a Etkisi: Kamu Çalışanları Üzerine Bir Araştırma. Yayımlanmamış Doktora Tezi, Süleyman Demirel Üniversitesi, Sosyal Bilimler Enstitüsü, Isparta.

Lam, S. S., Schaubroeck, J. and Aryee, S. (2002). Relationship between organizational justice and employee work outcomes: a cross-national study, Journal of Organizational Behavior, 23(1) : 1-18.

Lamprakis, A., Alamanı, K., Malliarı, A. and Grivas, I. (2018). The Organisational Justice as a Human Resources Management Practice and its Impact on Employee Engagement: The case of the Prefecture of Attica (Greece). Scientific Annals of Economics and Business, 65(1) : 65-79.

Li, S., Li, X. and Shi, K. (2010). The influence of procedure justice on work engagement: The mediating role of organizational commitment., Zhu, T., Gao, Q. and Li, B., in 2010 IEEE 2nd Symposium on Web Society, Beijing, China, 16-17 Agust 2010, IEEE Press, 632-636.

Lin, C. P. (2010). Modeling corporate citizenship, organizational trust, and work engagement based on attachment theory, Journal of Business Ethics, 94(4) : 517-531.

Lipponen, J., Olkkonen, M. E. and Moilanen, M. (2004). Perceived procedural justice and employee responses to an organizational merger, European Journal of Work and Organizational Psychology, 13(3) : 391-413.

Luthans, F., Luthans, K. W., and Luthans, B. C. (2004). Positive psychological capital: Beyond human and social capital, Business Horizons, 47(1) : 45-50.

McAllister, D. J. (1995). Affect-and cognition-based trust as foundations for interpersonal cooperation in organizations, Academy of Management Journal, 38(1) : 24-59.

Moon, H., Kamdar, D., Mayer, D. M., and Takeuch, R. (2008). Me or we? The role of personality and justice as other-centered antecedents to innovative citizenship behaviors within organizations, Journal of Applied Psychology, 93(1) : 84-94.

Moorman, R. H. (1991). Relationship between organizational justice and organizational citizenship behaviors: do fairness perceptions influence employee citizenship?, Journal of Applied Psychology, 76(6) : 845-855.

Nedkovski, V., Guerci, M., De Battisti, F. and Siletti, E. (2017). Organizational ethical climates and employee's trust in colleagues, the supervisor, and the organization, Journal of Business Research, 71 : 19-26.

Niehoff, B. P. and Moorman, R. H. (1993). Justice as a Mediator of the Relationship between Methods of Monitoring and OrganizationalCitizenship Behavior, The Academy of Management Journal, 36(3) : 527556.

Nowakowski, J. M. and Conlon, D. E. (2005). Organizational justice: Looking back, looking forward, International Journal of Conflict Management, 16(1) : 4-29.

Olkkonen, M. E. and Lipponen, J. (2006). Relationships between organizational justice, identification with organization and work unit, and group-related outcomes, Organizational Behavior and Human Decision Processes, 100(2) : 202-215.

Özdemir, Ö. (2015). Hizmetkar liderliğin lidere duyulan güven aracılığı ile işe adanmışlık üzerindeki etkisi, Yayımlanmamış Doktora Tezi, Arel Üniversitesi, Sosyal Bilimler Enstitüsü, İstanbul. 


\section{M. Öztürk - K. Vatansever 12/4 (2020) 3613-3632}

Özkalp, E. and Meydan, B. (2015). Schaufeli ve Bakker tarafindan geliştirilmiş olan İşe Angaje Olma ölçeğinin Türkçe'de güvenilirlik ve geçerliliğinin analizi, ISGUC The Journal of Industrial Relations and Human Resources, 17(3), 1-19.

Özmen, Ö. N., Arbak, Y. and Özer, P. S. (2007). Adalete Verilen Değerin Adalet Algıları Üzerindeki Etkisinin Sorgulanmasına İlişkin Bir Araştırma, Ege Akademik Bakış Dergisi, 7(1) : 19-35.

Park, Y., Song, J. H., and Lim, D. H. (2016). Organizational justice and work engagement: The mediating effect of self-leadership, Leadership \& Organization Development Journal, 37 (6) : 711-729.

Pfeffer, J. and Langton, N. (1993). The effect of wage dispersion on satisfaction, productivity, and working collaboratively: Evidence from college and university faculty, Administrative Science Quarterly, 3(38) : 382-407.

Polat, S. (2007). Ortaöğretim öğretmenlerinin örgütsel adalet algllarl, örgütsel güven düzeyleri ile örgütsel vatandaşlı davranışları arasındaki ilişki. Yayımlanmamış Doktora Tezi, Kocaeli Üniversitesi, Sosyal Bilimler Enstitüsü, Kocaeli.

Proost, K., Pavlinska, A., Baillien, E., Brebels, L. and Van Den Broeck, A. (2013). Employees' intention to blow the whistle: The role of fairness and moral identity, Psihologia Resurselor Umane, 11(2) : 15-27.

Sakallı, S. Ö. (2015). Örgütsel adalet ile örgütsel güven ilişkisinde kişilik özelliklerinin düzenleyici rolü ve bir alan araştırması, Yayımlanmamış Doktora Tezi, Balıkesir Üniversitesi, Sosyal Bilimler Enstitüsü, Balıkesir.

Saunders, M. and Thornhill, A. (2004). Trust and mistrust in organizations: An exploration using an organizational justice framework, European Journal of Work and Organizational Psychology, 13(4) : 493515.

Scandura, T. A. (1999). Rethinking leader-member exchange: An organizational justice perspective, The Leadership Quarterly, 10(1) : 25-40.

Seifert, D. L., Stammerjohan, W. W. and Martin, R. B. (2013). Trust, Organizational Justice, and Whistleblowing: A Research Note, Behavioral Research in Accounting, 26(1) : 157-168.

Sharma, H. and Yadav, R. (2018). The relationship between organizational justice and work engagement: trust as a mediator, Prabandhan: Indian Journal of Management, 11(3) : 50-61.

Simpson, M.R (2009). Predictors of Work Engagement Among Medical-Surgical Registered Nurses, Western Journal of Nursing Research, 31 (1) : 44-65.

Strom, D. L., Sears, K. L. and Kelly, K. M. (2014). Work engagement: The roles of organizational justice and leadership style in predicting engagement among employees, Journal of leadership \& organizational studies, 21(1) : 71-82.

Tenenhausa, M., Vinzi, V.E., Chatelinc, Y.M. and Lauro, C. (2005). PLS Path Modeling. Computational Statistics $\mathcal{E}$ Data Analysis, 48(1): 159-205.

Thorn, D. (2010). Perceptions of organizational justice, job satisfaction, and organizational commitment in intercollegiate athletics: a study of NCAA men's sport coaches. Yayımlanmamış Doktora Tezi, University of Loisville, Loisville.

TDK, Türk Dil Kurumu, Adalet, https://sozluk.gov.tr/. (Erişim Tarihi: 15 Haziran 2020).

Topaloğlu, I. G. (2010). İsgörenlerin adalet ve etik algıları açısından örgütsel güven ile örgütsel bağlllık ilişkisi, Yayımlanmamış Yüksek Lisans Tezi, Atılım Üniversitesi, Sosyal Bilimler Enstitüsü, Ankara.

Ugwu, F. O., Onyishi, I. E. and Rodroguez-Sanchez, A. M. (2014). Linking organizational trust with employee engagement: The role of psychological empowerment, Personnel Review, 3(43) : 377-400.

Uğurlu, C. T. and Üstüner, M. (2011). Öğretmenlerin örgütsel bağlllık düzeylerine yöneticilerinin etik liderlik ve örgütsel adalet davranışlarının etkisi, Hacettepe Üniversitesi Ĕ̆itim Fakültesi Dergisi, 41(41) : 434-448.

Urbach, N. and Ahleman, F. (2010). Structural Equation Modeling in Information Systems Research Using Partial Least Squares, Journal of Information Technology Theory and Application, 11(2) : 5-40. 
M. Öztürk - K. Vatansever 12/4 (2020) 3613-3632

Wetzels, M., Odekerken-Schroderl, G. and Oppen, C.V. (2008). Examining Healthcare Professionals Acceptance of Electronic Medical Records Using UTAUT, Issues in Information Systems, 9(2) : 396-401.

Wong, Y. T., Ngo, H. Y. and Wong, C. S. (2006). Perceived organizational justice, trust, and OCB: A study of Chinese workers in joint ventures and state-owned enterprises, Journal of World Business, 41(4) : 344355.

Yazıcıŏ̆lu, İ. (2009). Konaklama işletmelerinde işgörenlerin örgütsel güven duygulari ile iş tatmini ve işten ayrılma niyetleri üzerine bir alan araştırması, Elektronik Sosyal Bilimler Dergisi, 8(30) : 235-249.

Yelboğa, A. (2012). Örgütsel adalet ile iş doyumu ilişkisi: Ampirik bir çalışma, Ege Akademik Bakış Dergisi, 12(2) : 171-182.

Yeniçeri, Ö., Demirel, Y. and Seçkin, Z. (2009). Örgütsel adalet ile duygusal tükenmişlik arasındaki ilişki: İmalat sanayi çalışanları üzerine bir araştırma, Karamanoğlu Mehmetbey Üniversitesi Sosyal ve Ekonomik Araştırmalar Dergisi, 2009 (1) : 83-99.

Yıldırım, F. (2007). İş doyumu ile örgütsel adalet ilişkisi, Ankara Üniversitesi SBF Dergisi, 62(1), 253-278.

Yıldırım, M. (2014). Psikolojik sözleşme ihlallerinin örgütsel güven ve örgütsel sinizm ile ilişkisi: Otel işletmeleri üzerine bir araştırma, Yayımlanmamış Doktora Tezi, Gazi Üniversitesi, Eğitim Bilimleri Enstitüsü, Ankara.

Yıldırım, M. (2019). Tükenmişlik ve örgütsel sessizlik ilişkisi: otel işletmelerinde bir araştırma. İşletme Araştırmaları Dergisi, 11(1), 358-371.

Yolaç, S. (2011). Yöneticinin Algılanan Liderlik Tarzı İle Yöneticiye Duyulan Güven Arasındaki İlişkide Lider Üye Etkileşiminin Rolü, Öneri Dergisi, 9(36) : 63-72.

Zand, D. E. (1972). Trust and managerial problem solving, Administrative Science Quarterly, 2(17) : $229-239$. 